\title{
Review \\ The Influence of Dietary Interventions on Chronic Kidney Disease-Mineral and Bone Disorder (CKD-MBD)
}

\author{
Jacek Rysz ${ }^{1}$, Beata Franczyk ${ }^{1}$, Robert Rokicki ${ }^{2}$ and Anna Gluba-Brzózka 1,*D \\ 1 Department of Nephrology, Hypertension and Family Medicine, Medical University of Lodz, \\ 90-549 Lodz, Poland; jacek.rysz@umed.lodz.pl (J.R.); bfranczyk-skora@wp.pl (B.F.) \\ 2 Clinic of Hand Surgery, Medical University of Lodz, 90-549 Lodz, Poland; robert.rokicki@umed.lodz.pl \\ * Correspondence: aniagluba@yahoo.pl; Tel.: +48-42-639-3750
}

check for updates

Citation: Rysz, J.; Franczyk, B.; Rokicki, R.; Gluba-Brzózka, A. The Influence of Dietary Interventions on Chronic Kidney Disease-Mineral and Bone Disorder (CKD-MBD). Nutrients 2021, 13, 2065. https://doi.org/ $10.3390 /$ nu13062065

Academic Editor: Sabrina Noel

Received: 14 May 2021

Accepted: 7 June 2021

Published: 16 June 2021

Publisher's Note: MDPI stays neutral with regard to jurisdictional claims in published maps and institutional affiliations.

Copyright: (c) 2021 by the authors. Licensee MDPI, Basel, Switzerland. This article is an open access article distributed under the terms and conditions of the Creative Commons Attribution (CC BY) license (https:// creativecommons.org/licenses/by/ $4.0 /)$.

\begin{abstract}
Chronic kidney disease is a health problem whose prevalence is increasing worldwide. The kidney plays an important role in the metabolism of minerals and bone health and therefore, even at the early stages of CKD, disturbances in bone metabolism are observed. In the course of CKD, various bone turnover or mineralization disturbances can develop including adynamic hyperparathyroid, mixed renal bone disease, osteomalacia. The increased risk of fragility fractures is present at any age in these patients. Nutritional treatment of patients with advanced stages of CKD is aiming at prevention or correction of signs, symptoms of renal failure, avoidance of protein-energy wasting (PEW), delaying or prevention of the occurrence of mineral/bone disturbances, and delaying the start of dialysis. The results of studies suggest that progressive protein restriction is beneficial with the progression of renal insufficiency; however, other aspects of dietary management of CKD patients, including changes in sodium, phosphorus, and energy intake, as well as the source of protein and lipids (animal or plant origin) should also be considered carefully. Energy intake must cover patients' energy requirement, in order to enable correct metabolic adaptation in the course of protein-restricted regimens and prevent negative nitrogen balance and protein-energy wasting.
\end{abstract}

Keywords: chronic kidney disease; bone metabolism; secondary hyperparathyroidism; dietary interventions

\section{Introduction}

Chronic kidney disease (CKD) is a health problem whose prevalence is increasing worldwide [1]. According to estimations, 5-10\% of the world population has CKD, as a result of the high prevalence of chronic diseases that are not well-controlled, such as arterial hypertension and diabetes mellitus [2]. Due to the fact that the kidney plays an important role in the metabolism of minerals and bone health, even at the early stages of CKD, disturbances in bone metabolism are observed and they progressively impair bone health $[3,4]$. Kidneys are the target organ of several hormones including parathormone (PTH) and fibroblast growth factor-23 (FGF-23), but also vitamin D is activated there [5]. In the course of chronic kidney disease, various bone turnover or mineralization disturbances can develop including adynamic, hyperparathyroid, mixed renal bone disease, osteomalacia, and osteoporosis; all of them may present with decreased bone mineral density (BMD) and/or be associated with fragility (including hip) fractures [6]. Changes in bone and mineral metabolism progress as kidney function declines [7]. In the early stages of CKD , CKD-mineral and bone disorder (CKD-MBD) is characterized by bone pain, bone fractures, skeletal deformities in growing children as well as decreased velocity in bone growth, abnormal height, and the calcification of vascular and other soft tissues [8,9]. Even asymptomatic individuals can present alterations in bone histology, such as osteitis fibrosa (characterized by high bone turnover due to hyperparathyroidism), adynamic bone disease (characterized by very low or lack of bone turnover frequently seen in patients with low PTH and low tissue-specific alkaline phosphatase activity) and osteomalacia (related to 
insufficient bone formation and mineralization) [6,10-12]. As the renal impairment aggravates, most patients develop more advanced bone and mineral metabolism disturbances, including renal osteodystrophy (ROD) manifested with bone pain, muscle-tendon rupture, pruritus, and increased incidence of fractures and CKD-mineral and bone disorder (CKDMBD), which describes a systemic disorder of mineral and bone metabolism due to CKD. The results of studies have demonstrated low bone mineral density (BMD) in patients with CKD stages 3a-5D and 1.5- to 2-fold higher risk of fractures than in the general population and in BMD-matched patients without CKD [6,13-16]. According to studies, CKD-MBD is a substantial contributor to diminished quality of life and enhanced risk of mortality and morbidity in this group of patients $[9,17,18]$. The results of observational studies have shown the relationship between abnormal levels of CKD-MBD markers and poor clinical outcomes in pre-dialysis and dialysis patients $[19,20]$. The presence of high phosphate and calcium levels accompanied by high or low PTH levels was associated with greater mortality in maintenance hemodialysis patients [21]. Many studies have indicated that higher levels of alkaline phosphatase correlated with amplified risk of hospitalization and death in patients with CKD stages 3-4 and HD [22,23]. Alkaline phosphatases play important role in the pathogenesis of vascular calcification, which could explain why its high levels are associated with increased mortality. Other studies have revealed a strong correlation between FGF23 levels and poor renal outcomes [24-26]. The studies of the impact of elevated FGF23 levels in CKD patients on all-cause and cardiovascular mortality provided conflicting results. Some of them revealed the relationship between high levels of FGF23 and increased mortality [26-28], while others found no significant association [29,30].

The main aim of this review is to present the issue of chronic kidney disease-mineral and bone disorder (CKD-MBD) and to summarize the results of numerous studies assessing the impact of various diets on its course in order to imply the best choice of nutritional intervention. The selection of articles for this literature review was based on a PubMed search (the terms "CKD-MBD" + "pathomechanism" + "diet" + "CKD" were applied). We focused mainly on randomized, controlled studies/trials and systematic reviews and meta-analyses.

\section{Pathogenesis of Chronic Kidney Disease-Mineral and Bone Disorder (CKD-MBD)}

The mechanisms underlying bone loss and fractures in CKD patients are complex and have not been completely understood. According to the definition contained in a position statement from Kidney Disease: Improving Global Outcomes (KDIGO) [17] chronic kidney disease-mineral and bone disorder (CKD-MBD) is a "systemic disorder of mineral and bone metabolism due to CKD manifested by either one or a combination of the following: abnormalities of calcium, phosphorus, PTH, or vitamin D metabolism, abnormalities in bone turnover, mineralization, volume, linear growth, or strength; or vascular or other soft tissue calcification".

The worsening of renal function is associated with the retention of phosphate resulting in hypocalcemia, hyperphosphatemia, and low 1,25(OH)2D3, all promoting parathyroid hormone (PTH) secretion which in consequence leads to increased phosphate excretion and the development of secondary hyperparathyroidism in advanced stages of CKD $[1,18]$. The mechanism enabling the counterbalancing of phosphate retention involves the enhanced production of fibroblast growth factor 23 (FGF-23) whose level rises very early in CKD. FGF-23 factor is derived from osteocytes and osteoblasts, and it is involved in direct bone-kidney and bone-parathyroid associations (e.g., the metabolism of vitamin D and phosphate) thus participating in the development of CKD-MBD [31].

Plasma FGF23 has been shown to stimulate the secretion of phosphate in the proximal renal tubule as a result of the downregulation of luminal sodium-dependent phosphate transporters expression. Also, it can reduce intestinal phosphate absorption via the inhibition of the NaPi cotransporter activity [32]. FGF23 was found to increase distal sodium reabsorption via the direct regulation of the thiazide-sensitive sodium-chloride transporter (NCC) level in the distal convoluted tubule as well as to stimulate calcium reabsorption via 
the activation of the apical calcium entry channel (transient receptor potential cation channel subfamily V member 5; TRPV5) in the distal tubule [33,34]. In the early stages of CKD, FGF23 down-regulates the activity of $1 \alpha$-hydroxylase and enhances 24 -hydroxylase activity which results in the decreased synthesis of 1,25-dihydroxyvitamin D [1,25(OH)2D3] [35,36]. Plasma levels of FGF23 gradually increase along with the worsening of renal function. Its secretion occurs earlier than changes in calcium, phosphorus, or PTH levels and therefore it is now recognized as one of the earliest detectable biomarkers of the CKD-MBD [37]. High levels of FGF23 diminish hyperphosphatemia reducing at the same time 1,25(OH)2 vitamin D levels [36]. The deficiency of calcitriol is associated with reduced intestinal calcium absorption, which results in hypocalcemia, decreases tissue levels of vitamin D receptors leading to the development of resistance to calcitriol-mediated regulation, the stimulation of PTH secretion and consequent secondary hyperparathyroidism [38]. The aggravation of renal injury and the related drop in the number of functioning nephrons, the maintenance of phosphate excretion is associated with FGF23 and PTH-stimulated decrease in tubular reabsorption of filtered phosphate in the remaining nephrons [39]. Due to the fact that Klotho deficiency limits the impact of FGF23 on phosphate excretion, PTH becomes the vital adaptive mechanism preserving phosphate homeostasis. Indeed, in dialysis patients, the ability of FGF23 to control phosphate levels via its phosphaturic effect as well as to normalize PTH secretion was demonstrated to be significantly reduced. In advanced CKD (stages 4-5), the aforementioned adaptation mechanism is no longer sufficient, and hyperphosphatemia develops in spite of high PTH and FGF23 levels [39].

The endocrine activity of FGF-23 requires its binding and the activation of its receptor complex containing a transmembrane protein Klotho [40,41]. The results of studies have indicated that the dysregulation of the FGF23-related compensatory mechanism in CKD patients is associated with Klotho deficiency [1]. In the early stages of CKD, the FGF23-Klotho axis was found imbalanced-high levels of FGF23 and reduced concentrations of Klotho were observed [1]. Apart from converting FGFR1(IIIc) into a specific receptor for FGF23, Klotho increases phosphaturia and prevents urinary calcium loss [42]. The decrease in the membrane-bound Klotho expression limits of FGF23-related signal transduction mediated by the FGF receptor/Klotho complexes leads to the loss of negative feedback in response to FGF23 secretion and subsequent persistent production and secretion of FGF23 by the osteocyte [43]. Its deficiency is, therefore, associated with mineral metabolism disorders, vascular calcifications, secondary hyperparathyroidism, and cardiac hypertrophy [40]. The increase in serum PTH observed from the early stages of CKD leads to enhanced bone resorption to maintain calcium balance. Prolonged hypersecretion of PTH is associated with high turnover bone disease and a greater risk of fractures and bone deformities [44]. Elevated serum phosphate has been demonstrated to reduce calcitriol synthesis and to precipitate in vessels and soft tissues with calcium, thus diminishing ionized calcium fraction and indirectly promoting PTH secretion [44]. Excessive PTH secretion associated with the reduction in serum 1,25(OH)2D3 and subsequent decrease in intestinal calcium absorption, as well as with low concentration of calcitriol and hyperphosphatemia leads to the mobilization of calcium from the bone and osteitis fibrosa [1,45]. Hyperphosphatemia promotes the transition of osteoblasts in the vessels stimulating extraskeletal mineralization and rising $\mathrm{Ca} \times \mathrm{P}$ product [39]. Increased levels of PTH are also associated with abnormal osteoblastic function and osteocyte stimulation with the receptor activator of NF- $\mathrm{kB}$ (RANK) ligand (RANK-L) leading to CKD mineralization defects, high bone turnover ROD, and bone resorption [46]. In CKD patients, the upregulation of RANK-L is accompanied by the downregulation of the osteoclast maturation inhibitor, osteoprotegerin (which protects from bone resorption), which in consequence favors bone resorption and increased bone turnover [47]. Numerous studies have demonstrated that the presence of kidney disease is associated with the reactivation of developmental programs involved in nephrogenesis during disease-stimulated renal repair, especially Wnt inhibitors (a portmanteau of wingless and int) such as Dickkopf-1 (Dkk1) and sclerotin [43,48,49]. These signal molecules are typically silent in the normal adult kidney [50]. The reactivation of the Wnt pathway regu- 
lating tubular epithelial proliferation and polarity during nephrogenesis is a driving force in renal fibrosis [48]. Wnt/ $B$-catenin pathway is considered to be one of the key regulators of bone formation since its activation stabilizes B-catenin-a transcription factor involved in the synthesis of many osteoblastic factors, including Runx2 and osterix [51]. B-catenin translocation to the nucleus becomes a triggering factor for osteoblastic genes and bone differentiation. Its activation enhances osteoblastic activity and intensifies bone formation [51]. It has been revealed that kidney disease-induced "unintended" systemic inhibition of Wnt activity is associated with severe consequences in the skeleton and vasculature, such as decreased bone formation rates, elevated FGF23 secretion, vascular calcification, and promotion of cardiac hypertrophy [43,50]. According to studies, activin A, belonging to TGF $\beta$ superfamily members, also plays a crucial role in the vascular and skeletal components of CKD-MBD [52]. It is secreted from the peritubular myofibroblast of injured kidneys and exerts its actions via type 2 activin A receptor (ActRIIA) [1,52]. Studies on animal models demonstrated that CKD-MBD, apart from elevated levels of FGF23, PTH, reduced Klotho hyperphosphatemia, osteodystrophy, vascular calcification, and cardiac hypertrophy, was characterized by the stimulation of ActRIIA. Moreover, the inhibition of ActRIIA signaling was associated with the reversal and attenuation of these features of CKD-MBD [52-54]. Recent studies have suggested that other factors may also modulate osteoblast function and may be involved in the development of the mineralization disorder of CKD thus leading to high turnover renal osteodystrophy, surplus bone resorption, skeletal frailty, and increased fracture risk $[43,55]$. The loss of bone strength despite an apparent increase in mass may be partly associated with the deposition of woven immature collagen fibrils instead of lamellar mature fibrils in the course of progressive renal impairment [56]. Overall bone balance determines whether patients with advanced CKD would experience gain or loss in bone volume [43]. Negative bone balance is associated with cortical and cancellous bone loss occurs which leads to osteopenia or osteoporosis [57]. In the case of positive bone balance, patients show osteosclerosis resulting from deposition composed primarily of immature woven collagen in new bones by osteoblasts [43]. However, the improvement of secondary hyperparathyroidism treatment nearly has ruled out this scenario. High-turnover renal osteodystrophy, observed in patients with secondary hyperparathyroidism with osteitis fibrosa, is characterized by bone resorption rates that exceed bone formation as well as osteopenia progressing to osteoporosis [58]. In turn, low-turnover renal osteodystrophy, diagnosed in those with over-treated secondary hyperparathyroidism is associated with decreased bone formation and resorption rates despite the fact that resorption is still in relative excess and loss of bone mass [59]. Patients with renal osteodystrophy are predisposed to cardiovascular calcification resulting in their higher morbidity and mortality $[17,60]$.

Chronic kidney disease also leads to the significantly decreased ability to generate new bicarbonate required to buffer the amount of acid generated by the tissues, which results in acidosis $[61,62]$. Chronic metabolic acidosis occurs early in the course of CKD. It affects bone fragility via enhanced secretion and resistance to PTH, higher osteoclastic activity, raised renal elimination of calcium, bone mineral dissolution, and malnutrition $[7,61,63]$. The accumulation of uremic toxins has been proven to influence bone quality in CKD patients since they affect bone metabolism and function by worsening bone quality and quantity [64] Indoxyl sulfate (IS), whose level increases as renal dysfunction progresses, down-regulates the expression of PTH receptor on osteoblasts and reduces the bone turnover as well as suppresses bone formation signaling by stimulating the secretion of Wnt antagonists from osteocyte $[6,65,66]$. Barreto et al. [67] found a positive correlation between IS levels and bone formation rate, osteoblasts surface area, osteoid volume, and bone fibrosis volume. Therefore, it seems that the decrease of gastrointestinal absorption and the increase in uremic toxin clearance may be important in the treatment of uremic osteoporosis.

\section{Diets}

In order to prevent the development of CKD-MBD, bone complication patients, as well as vascular or other soft tissue calcification CKD patients, should be offered not only 
treatment but also appropriate nutritional counseling [9]. Current research indicates that phosphate retention plays a significant role in the development of CKD-MBD. It seems that the control of phosphate homeostasis early in CKD may help to diminish adverse clinical consequences of mineral and bone disorders. Dietary phosphate restriction and the use of phosphate binders are two basic measures for the management of increased phosphate levels. Dietary interventions seem to be uncomplicated, inexpensive, and practical in comparison with drug therapies. The results of studies suggest that prolonged limiting of dietary phosphate intake can effectively prevent the development of secondary hyperparathyroidism, and this approach can be implemented in patients with all stages of kidney disease $[68,69]$. Therefore, dietary phosphate restriction is recommended in many guidelines. According to the KDOQI 2003 guidelines, dietary phosphorus should be restricted to $800-1000 \mathrm{mg} /$ day in CKD patients with plasma levels of intact PTH exceeding the target range of the CKD stage [70]. The KDIGO 2009 guidelines suggest that dietary phosphate intake should be limited in patients with CKD stages 3 to 5D in order to treat hyperphosphataemia; however, the evidence to support this recommendation is currently weak $[9,71]$.

\subsection{Low Phosphate Diet/PPR Diet}

The systematic review of randomized controlled trials revealed that serum phosphorus was significantly decreased in patients on a low phosphorus intake diet compared to a normal diet (MD $-0.18 \mathrm{mmol} / \mathrm{L}, 95 \% \mathrm{CI}-0.29$ to $-0.07 ; \mathrm{I} 2=0 \%$ ) [9]. In turn, Isakova et al. [72] demonstrated considerably lower concentrations of PTH with low phosphorous intake compared to ad libitum diet (MD $25.60 \mathrm{pg} / \mathrm{mL}, 95 \%$ CI 5.13 to 46.07). However, phosphate restriction with the addition of a binder seems to be better than the restriction alone. A randomized controlled trial of patients with CKD stages 3-4 and normal serum phosphate levels showed that consumption of low-phosphorous products and the addition of phosphate binders were more efficient in the reduction of serum FGF-23 than either approach alone $[72,73]$. Other systematic review and meta-analyses assessing the effect of phosphate-specific diet therapy on serum phosphate in patients undergoing HD revealed that monthly diet-therapy sessions (lasting approximately 20-30 min) could considerably decrease serum phosphate in adults on HD with hyperphosphatemia over a 6-month period (two RCTs [74,75]), while a single session of diet therapy could reduce serum phosphate in adults with hyperphosphatemia for up to 3 months (one RCT [76]) [77]. The authors suggested that the impact of diet on serum phosphate could be associated with diminished dietary phosphate load. Patients on phosphate-specific diets claimed to adhere to specific strategies involving the avoidance of phosphate additives and limitation of phosphate-rich foods intake [77]. Dietary phosphate restriction is used commonly to improve outcomes, but the fact that phosphate intake usually parallels protein intake makes the situation more complicated as CKD patients need to receive an adequate amount of dietary protein to avoid malnutrition [78]. Muscular wasting CKD has been observed in the course of $\mathrm{CKD}$ and therefore there are concerns about potential catabolic and cachectic effects of LPD/VLPD. Therefore, recently an approach has been offered that considers the phosphate to protein ratio PPR (the phosphorus content per gram of protein) [79]. Such a strategy has several benefits as dietary management for CKD patients with hyperphosphatemia. Firstly, it concentrates concurrently on both proteins and phosphates, which are vital for the nutritional treatment of CDK, and it is independent of the portion size or serving [79]. Moreover, the calculated ratio enables patients to select from two similar options with different amounts of phosphorus but almost equal amounts of protein [80]. The utilization of this approach allows for the maintenance of proper protein intake including foods with low PPR, avoidance of a high phosphate load, and also the appropriate inclusion of low phosphate vegetables, fruits, and cereals into the diet [79]. 


\subsection{Low-Protein Diets and Supplemented Very-Low-Protein Diets}

According to studies, patients with advanced CKD (stages 4 and 5) who are on reduced phosphate and protein intake diet show improved short-term control of secondary hyperparathyroidism [81-83]. The adjustment of dietary protein intake is a cornerstone of nutrition therapy in patients with CKD $[84,85]$. The recommendation often varies between very-low (VLPD) diets containing $0.3-0.4 \mathrm{~g}$ of protein $/ \mathrm{kg} / \mathrm{d}$ supplemented with alpha-keto acid (KA) analogues of essential amino acids and low-protein diets (LPD) comprising $0.6-0.8 \mathrm{~g}$ protein $/ \mathrm{kg} / \mathrm{d}$ and usually no KA supplementation $[86,87]$. The analysis of NHANES data revealed that dietary protein intake observed in most stages of pre-dialysis CKD patients exceeded recommended dietary allowance (RDA) $(0.8 \mathrm{~g} / \mathrm{kg} /$ day of protein) [88]. To facilitate the decrease of protein intake, Fois et al. [89] suggested a stepwise approach involving the preliminary reduction of dietary protein intake to RDA followed by the transition into LPD within a 2- to 6-week period and ending with the switching to (if desired) VLPD + KA analog diet. Numerous studies have indicated that LPD exert beneficial effects on markers of CKD-MBD, especially when it is combined with KA supplementation [85].

In the long perspective, reduction of phosphate and protein intake allowed some patients to accomplish a normal rate of bone formation [90]. Another study indicated that intensive restriction of protein and phosphate intake reduced FGF-23 and serum phosphorus levels compared to a low-protein diet [91]. A secondary analysis of the Modification of Diet in Renal Disease (MDRD) study revealed that a lower protein intake $(0.87 \mathrm{~g}$ protein $/ \mathrm{kg} /$ day) was associated with a slight reduction in serum phosphorus that was sustained over a three-year period compared to standard protein intake (1.12 $\mathrm{g}$ protein $/ \mathrm{kg}$ /day) [92].

In turn, Liu et al. [9] demonstrated that very low protein intake was more effective in diminishing PTH level compared to low protein intake (MD $-69.64 \mathrm{pmol} / \mathrm{L}, 95 \% \mathrm{CI}$ -139.83 to $0.54 ; \mathrm{I} 2=57 \%$ ). However, they also observed that very low protein intake was not superior to conventional low protein intake in terms of impact on serum phosphorus (MD $-0.12 \mathrm{mmol} / \mathrm{L}, 95 \% \mathrm{CI}-0.50$ to 0.25 ), serum calcium (MD $0.00 \mathrm{mmol} / \mathrm{L}, 95 \% \mathrm{CI}$ -0.17 to 0.17 ), or alkaline phosphatase (MD $-22.00 \mathrm{U} / \mathrm{L}, 95 \% \mathrm{CI}-78.25$ to 34.25) [9]. Moreover, Herselman et al. [93] found that very low protein intake ( $0.4 \mathrm{~g}$ protein $/ \mathrm{kg} / \mathrm{d})$ and low protein intake $(0.6 \mathrm{~g}$ protein $/ \mathrm{kg} / \mathrm{d}$ ) (MD $0.00 \mathrm{mmol} / \mathrm{L}, 95 \% \mathrm{CI}-0.17$ to 0.17 ) did not significantly influence body mass index, arm muscle area, percentage body fat. They also had no effect on serum levels of parathyroid hormone and alkaline phosphatase, tubular reabsorption of phosphate, and the theoretical renal threshold for phosphate. The effect of various contents of protein in the diet on bone mineral density (BMD) or T scores $(p<0.0001)$ was also analyzed by Lee et al. [94] in 12,812 patients from the National Health and Nutrition Examination Survey database. In their analysis, the highest bone BMD and T scores were reported in the group with the highest protein intake $(p<0.0001)$ [95]. In case of femoral BMD, higher protein diets were associated with higher BMD in the femoral neck, trochanter, intertrochanteric, and total femoral areas $(p=0.032,0.0036,0.008$, and 0.0039, respectively) but only in patients without CKD [94]. Therefore, it seems that diets containing higher amounts of protein result in higher femoral BMD only in subjects without CKD. In general, it seems that LPD may prove beneficial in mineral and bone metabolism compared to normal- or high-protein diets due to related dietary phosphorus intake [95].

The results of some recent studies have suggested that restricted very-low protein diets (VLDP), supplemented with ketoacid analogs (KAs) may not only improve renal function, but also prevent hyperparathyroidism, the accumulation of uremic retention solutes and insulin resistance [96]. It remains unknown whether KA supplementation alone exerts any beneficial effects on metabolic disturbances related to CKD. Randomized controlled trial of non-diabetic CKD 3b-4 stage patients ascribed to either LPD diet $(0.6 \mathrm{~g} / \mathrm{kg}$ of body weight/day) alone or with the supplementation of KA and demonstrated that the latter diet considerably diminished serum phosphorus, PTH, and FGF23 and increased 
serum Klotho in patients [97]. Lineadeau et al. [98] demonstrated an improvement in osteofibrotic and osteomalacic changes on bone biopsies after 12 months of treatment with KAs, which was independent of calcium intake. In turn, the study of patients with early $\left(\mathrm{eGFR}>60 \mathrm{~mL} / \mathrm{min} / 1.73 \mathrm{~m}^{2}\right)$ and advanced stages of CKD $\left(<30 \mathrm{~mL} / \mathrm{min} / 1.73 \mathrm{~m}^{2}\right)$ on LPD demonstrated that this diet reduced intact FGF23 levels in both groups, while the decrease in serum phosphorus and PTH was seen only in advanced CKD [99]. KA supplementation can be used in combination with an LPD; however, it is most commonly prescribed with a VPLD [85]. There are several randomized controlled trials evaluating the impact of VLPD + KA on biochemical markers of CKD-MBD. The meta-analysis of 17 RCTs and 1459 participants assessing the safety and effectiveness of a restricted protein diet supplemented with KAs compared with regular diet or low protein diet (LPD) without KAs in CKD patients revealed that the first one not only preserved eGFR but also decreased proteinuria, serum phosphate, parathyroid hormone (PTH) level [100]. Only VLPD with KAs significantly improved serum PTH, while only LPD with KAs significantly increased serum albumin and serum calcium [100]. A systematic review and meta-analysis of five clinical trials assessing the effects of VLPD + KA in dialysis ESKD patients indicated a reduction in serum phosphorus of $-1.14 \mathrm{mg} / \mathrm{dl}(95 \% \mathrm{CI}-1.98,-0.28)$ and a mean decrease in PTH of $-212.35 \mathrm{ng} / \mathrm{mL}$ (95\% CI -294.28, -130.42) with VLPD + KA [101]. The comparison of VLPD + KA (for 3 months) and Mediterranean-based diet or usual diet in moderate staged CKD patients (stages $3 \mathrm{~b}-4$; eGFR $15-45 \mathrm{~mL} / \mathrm{min} / 1.73 \mathrm{~m}^{2}$ ) revealed that the first diet was associated with a decrease in serum phosphorus and PTH as well as lowered FGF23 levels $[91,102]$. However, some other studies found that very low protein intake was not superior to the conventional low protein diet in terms of the effect on serum calcium, phosphorus, and alkaline phosphatase levels [103,104]. Low protein intake supplemented with keto-acids was shown to decrease serum phosphorus in patients undergoing hemodialysis compared with normal protein intake [104]. However, no differences in PTH and alkaline phosphatase were observed when hemodialysis patients adopted a hypolipidemic diet compared with statins [105]. Chauveau et al. [106] demonstrated that VLPD + KA may also exert an effect on bone mineral density. In advanced-staged patients, pre-dialysis CKD patients (eGFR $15 \pm 4.7 \mathrm{~mL} / \mathrm{min} / 1.73 \mathrm{~m}^{2}$ ) the consumption of VLPD + KA for years induced initial decline in lean body mass (after 3 months) followed by stabilization at 6 months and then a significant increase from 6 to 24 months ( $p=0.02$, paired t-test). Moreover, they observed a significant reduction in total bone mass, lumbar or hip site bone mass, and Z-score from T0 to 1 and 2 years $(p<0.05)$. However, more studies are required to evaluate the direct effect of LPD and VLPD on bone outcomes in CKD patients. In general, many trials have demonstrated that VLPD + KA may beneficially affect biochemical markers of CKD-MBD. However, due to the fact that KA is provided in the form of calcium salts, there is a potentially increased risk for calcium retention related to high calcium burden $[107,108]$. Dietary protein reduction has been shown to diminish the risk of adverse outcomes related to high phosphate diets, such as renal osteodystrophy, left ventricular hypertrophy, and the progression of CKD [73]. Some studies have suggested that it can also help to decrease elevated FGF-23 levels which are associated with enhanced cardiovascular events and mortality risk [26,109].

\subsection{High-Protein Diets in CKD and ESKD}

In contrast to pre-dialysis CKD patients who are recommended dietary protein restrictions, a high protein intake is suggested for patients with dialysis ESKD in order to make up for the increased protein requirements, and protein losses during dialysis [84]. According to guidelines, HD patients are recommended to consume $1.2 \mathrm{~g}$ of protein $/ \mathrm{kg} / \mathrm{d}$, while protein intake of patients on peritoneal dialysis should be in the range of 1.2-1.3 g of protein $/ \mathrm{kg} / \mathrm{d}$ to $1.5 \mathrm{~g} / \mathrm{kg} / \mathrm{d}$ (in case of peritonitis) [84,86]. Dietary protein has been demonstrated to exert beneficial effects on bone health due to the fact that it elevates the level of insulin-like growth factor 1 (IGF-1) which enhances the activity of osteoblasts and fractional calcium absorption, decreasing at the same time osteoclast activity $[85,110]$. 
Recent meta-analyses have confirmed the relationship between higher dietary intake of protein and higher total bone mineral density in healthy individuals [111]. A post-hoc analysis of the IHOPE trial revealed that 12-month supplementation of $30 \mathrm{~g}$ of whey protein with or without intradialytic bicycling prevented the yearly decrease in total and hip bone mineral density in elderly individuals [112]. On the other hand, higher dietary protein can increase endogenous acid production and net acid excretion which in patients with already compromised acid-base balance as a result of kidney dysfunction may negatively influence bone health [113]. Moreover, a high protein content diet is strongly associated with a high phosphorus intake which may also not be beneficial in this group of patients [79]. However, there are hardly any studies on the effect of higher dietary protein intake on biochemical markers of mineral and bone metabolism, bone, and vascular calcification in dialysis patients thus it is difficult to draw any conclusions.

\subsection{Plant-Based Diets}

Recent evidence implies that the source of phosphates in the diet (plant- vs. animalbased food), not only their content, is of importance [114]. Plant-based diets have been demonstrated to be advantageous as they help to reduce risk factors for many chronic diseases, including CKD [85]. Being on such a diet is associated with lower consumption of proteins and thus phosphorus and sulfur-containing amino acids and acid load [115]. The correction of potential metabolic acidosis in CKD patients resulting from diminished acid load translates to benefits to bones [85,116,117]. Goraya et al. [118] indicated that increasing consumption of fruits and vegetables improved (within a year) markers metabolic acidosis in moderate CKD patients. Plant-derived dietary phosphates are mostly in the form of less digestible (in humans) phytates and therefore, after their intake, they are less bioavailable compared to phosphates derived from animal sources [114]. A small study of patients with diagnosed CKD (mean eGFR $32 \mathrm{~mL} / \mathrm{min} / 1.73 \mathrm{~m}^{2}$ ) demonstrated that after one week of the dietary intervention (consumption of vegetarian- vs. meat-based diets with equivalent contents of protein and phosphates) the vegetarian diet resulted in lower serum levels of phosphorus and FGF-23 compared to meat-based diet [119]. In turn, Moorthi et al. [120] observed that the conversion from an animal protein-based diet to a 70\% plant-protein diet was associated with a significant reduction of urinary phosphorous excretion, but not serum phosphorous or FGF-23 levels in patients with stages 3-5 CKD. Soroka et al. [121] analyzed the effects of low phosphate diets and found that a low-phosphorus vegan diet containing only an appropriate cereal-legume mixture was equally effective as a conventional low-protein diet. In their study, patients not only avoided protein malnutrition but also decreased phosphate intake despite its abundance in animal-based foods [9]. On the other hand, higher phytate intake may lead to deficiencies of some minerals such as iron, zinc, and calcium [79]. However, further studies of plant-based diets in CKD are required to analyze their beneficial effects in terms of bone health.

\subsection{Other Approaches}

Some studies have suggested the existence of a relationship between obesity, energydense diets, and mineral metabolism in CKD [122]. According to them, energy-dense food generally tends to contain low levels of $\mathrm{Ca}$ and also to decrease its intestinal absorption as a result of the interaction between Ca and lipids in the intestinal lumen and subsequent formation of Ca soaps [123,124]. Therefore, being on energy-dense diets may lead to negative $\mathrm{Ca}$ balance, and ultimately aggravate hypocalcemia in patients with CKD-MBD. Moreover, such products are typically rich in inorganic $\mathrm{P}$ (food additive) which is more easily absorbed compared with the organic P naturally contained in food [125]. Again, high-fat content in the diet enhances P digestibility, further aggravating P load [126]. The aforementioned trapping of $\mathrm{Ca}$ in Ca soaps reduces the formation of insoluble $\mathrm{Ca}-\mathrm{P}$ complexes, thus allowing for the absorption of higher levels of $P$ ions [126]. Data from animal studies seem to confirm that energy-dense diets could contribute to P retention in individuals with decreased renal function. Phosphorus overload is especially harmful 
for CKD-MBD patients, due to the risk of adverse consequences, including soft tissue mineralization and the progression of renal disease. Therefore, apart from malnourished individuals, energy-dense diets are inadequate for CKD-MBD patients, due to their impact on P metabolism. The above-mentioned energy-dense food-related decrease in Ca load and elevation of $\mathrm{P}$ load could exert a direct impact on parathyroid glands, leading to the increased secretion of PTH as well indirectly affecting PTH concentration via the promotion of hyperlipidemia and hyperleptinemia. The ingestion of a high calorie/high-fat diet has been also shown to increase plasma concentrations of FGF23 and the effect was independent of obesity $[127,128]$. It seems that the mechanism for increased FGF23 following the intake of energy-dense diets may be associated with the decrease in renal Klotho and subsequent tubular resistance to FGF23. At that time more FGF23 is required to maintain phosphaturia, which, in consequence, leads to the raise in circulating levels of FGF23 [129]. Moreover, high content of fat and obesity may stimulate systemic inflammation and renal injury which could also affect FGF23 [130,131].

However, currently, international guidelines failed to reach a complete agreement regarding the optimal amount of dietary proteins for CKD patients. A randomized controlled trial provided preliminary evidence that in CKD patients a protein intake of $0.55 \mathrm{~g} / \mathrm{kg} /$ day guaranteed a better metabolic control and a decreased need of drugs, without a substantial risk of malnutrition, compared with a $0.8 \mathrm{~g} / \mathrm{kg} /$ day intake [132].

The most important results obtained in the aforementioned studies concerning the impact of dietary interventions on CKD-MBD are summarized in Table 1.

Table 1. Study group.

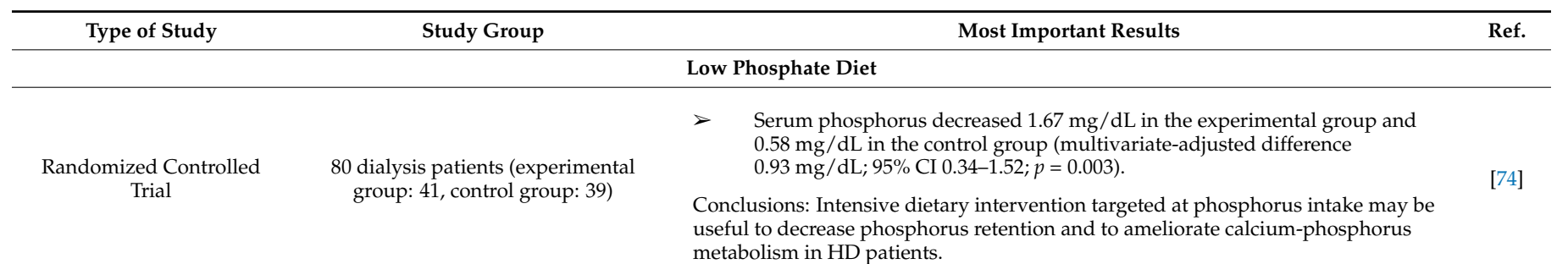
metabolism in HD patients.

- Calcium-enriched bread increased serum calcium (MD $-0.16 \mathrm{mmol} / \mathrm{L}, 95 \%$ $\mathrm{CI}-0.51$ to -0.31 ), reduced serum phosphorus ( 53 participants: MD $-0.41 \mathrm{mmol} / \mathrm{L}, 95 \% \mathrm{CI}-0.51$ to -0.31$)$, and diminished the calcium $\times$ phosphate product (53 participants: $\mathrm{MD}-0.62 \mathrm{mmol}^{2} / \mathrm{L}^{2}, 95 \% \mathrm{CI}-0.77$ to -0.47 ;

Review of 9 studies $\quad 634$ participants $>\quad$ Low phosphorus intake reduced serum phosphorus (359 participants: MD $-0.18 \mathrm{mmol} / \mathrm{L}, 95 \% \mathrm{CI}-0.29$ to $-0.07 ; \mathrm{I}(2)=0 \%$ ).

Conclusions: limited low-quality evidence indicating that dietary interventions (calcium-enriched bread may positively influence CKD-MBD by increasing serum calcium, lowering serum phosphorus, the calcium $\times$ phosphate product, and FGF-23

> 900-mg phosphate diet compared with ad libitum diet-no significant

39 patients with CKD stages 3 or 4 and normal serum phosphate levels randomly assigned to: (a) ad libitum diet + LC placebo $(n=10)$, (b) $900-\mathrm{mg}$ phosphate diet + LC placebo $(n=10)$, (c) ad libitum diet + LC $(n=11)$ or $(\mathrm{d})$ 900-mg phosphate diet + LC $(n=8)$

reduction in FGF23 levels.

- LC alone compared with placebo-no significant reduction in FGF23 levels;

$>\quad$ Combined intervention significantly diminished FGF23 levels throughout the study period resulting in a $35 \%(95 \% \mathrm{Cl} 8 \%$ to $62 \%)$ reduction by the end of study.

Conclusions: Combination of LC plus counseling for a phosphate-restricted diet decreased FGF23 levels in patients with CKD stages 3-4 and normal serum phosphate levels.

> After 6 months, significantly higher gains in knowledge in the intervention group, and considerably lower serum phosphorus and calcium/phosphorus product levels $(p<0.01)$ than in the control group.

Conclusion: Patients who received extra education monthly showed positive changes, which may be beneficial in reducing hyperphosphatemia.

Clinical trial. Educational intervention and one-to-one teaching session with renal dietitian
63 dialysis (experimental group: 32 of additional diet education on monthly laboratory values and management
- Significantly decreased serum phosphate after the education session in the

56 stable adult hemodialysis patients with hyperphosphatemia intervention group compared to patients' previous results;

- Improved results were sustained over a period of 3 months.

Conclusion: Dietetic educational intervention can favorably alter patients' serum phosphate levels, with potential impact on morbidity and mortality. 
Table 1. Cont.

\begin{tabular}{cc}
\hline Type of Study & \multicolumn{1}{c}{ Study Group } \\
\hline Low-Protein Diets \\
Review of 9 studies \\
634 participants \\
\\
\\
Clinical trial \\
22 with CRF randomly assigned to a \\
conventional low-protein diet $(0.6 \mathrm{~g}$ \\
protein/kg/day) or a \\
very-low-protein diet $(0.4 \mathrm{~g}$ \\
protein/kg/day) supplemented with \\
essential AA
\end{tabular}


Table 1. Cont.

\begin{tabular}{cc}
\hline Type of Study & Study Group \\
\hline & 60 patients with CKD grades 3B-4 \\
assigned to: (a) 3 months of free diet \\
(FD), 6 months of VLPD, 3 months of \\
Frospective, randomized, \\
FD and 6 months of MD; and (b) \\
3 months of FD, 6 months of MD, \\
3 months of FD and 6 months of VLPD \\
\\
\\
A prospective, \\
randomized, controlled \\
crossover study
\end{tabular}

CKD patients receiving a

A post hoc analysis of the MDRD Study

Clinical trial

Patients with early $(n=15)$ and advanced $(n=20)$ CKD usual-protein (UP) or low-protein (LP)

diet in study A or an LP or very LP

(VLP) with ketoacids diet in study B

Most Important Results Ref.

> MD and VLPD was associated with lower diastolic BP pressure and reduced serum levels of urea, sodium, phosphorus, and parathyroid hormone, as well as higher serum levels of bicarbonate and hemoglobin;

$>\quad$ Both MD and VLPD, when compared with FD, were related to reduction in serum Hcit levels and Hcit/Lys ratios $(p<0.001)$.

Conclusion: Nutritional treatments which significantly diminished serum levels of urea are associated with reduced protein carbamylation.

$>$ One week of the very-low-protein diet was associated with a decrease in FGF23 levels (33.5\%), serum phosphate $(12 \%)$, and urinary phosphate $(34 \%)$ compared with the low-protein diet;

$>\quad$ Serum and urinary phosphate levels and protein intake were significant determinants of FGF23 (95\% Cl 1.04 to $1.19,1.12$ to 1.37 , and 1.51 to 2.23 , respectively).

Conclusions: A very-low-protein diet supplemented with ketoanalogs reduced fibroblast growth factor 23 levels in CKD patients not yet on dialysis.

$>\quad$ Dietary protein restriction effectively reduced urinary phosphate levels and was associated with a very modest but sustained decrease in serum phosphate levels;

$>\quad$ Patients with mild CKD achieved stable serum phosphate levels over 3 years.

\section{- Decreased serum FGF23 levels in both groups;}

$>\quad$ Changes in FGF23 levels correlated with changes in $24 \mathrm{~h}$ urinary

phosphorus excretion in the advanced CKD group;

- Decreased serum intact parathyroid hormone levels only in the advanced CKD group;

Increased serum 1,25-dihydroxyvitamin D levels only in the early CKD group.

Conclusions: Consuming a standard low-protein diet decreased serum FGF23 levels in patients with CKD. Serum FGF23 levels may therefore be a useful marker to monitor the effects of a low-protein diet in early and advanced stage CKD.

- Significantly decreased serum phosphorus level and calcium-phosphate

40 MHD patients with uncontrolled hyperphosphatemia randomized into either low SLP or NP group for 8

Clinical trial weeks. After 8 weeks, the sLP group was shifted to NP for another 8 weeks. product at the end of the first 8 weeks in the SLP group vs. the basal value and the NP group $(p<0.001)$;

$>\quad$ No difference in $\mathrm{C}$-reactive protein, $\mathrm{Kt} / \mathrm{V}$, and nutritional index.

Conclusion: Short-term restriction of DPI supplemented with keto acids could decrease hyperphosphatemia and calcium-phosphate product, while keeping stable nutritional status among MHD patients.

- GFR, albumin, and pre-albumin levels remained stable;

13 stable patients with GFR $15 \pm 5 \mathrm{~mL} / \mathrm{min}$ receiving a VLPD $(0.3 \mathrm{~g} / \mathrm{kg} /$ day protein) supplemented with AA and KAs 2 years;

- No significant change in total fat mass or percent fat mass;

- Total bone mass, lumbar or hip site bone mass, and Z-score significantly decreased from T0 to 1 and 2 years $(p<0.05)$.

Conclusion: A supplemented VLPD is nutritionally safe for a long period, but attention must be paid to bone mass.

\section{High-Protein Diets in CKD and ESKD}

Observational study

Women $(n=39,066)$ and men $(n=31,149)$ from UK Biobank (participants aged $40-69$ years)

$>\quad$ Positive and linear association between protein intake and BMD in women ( $\beta$-coefficient 0.010 [95\% CI 0.005; 0.015, $p<0.0001]$ ) and men $(\beta$-coefficient 0.008 [95\% CI 0.000; $0.015, p=0.044]$ ).

Conclusions: Higher protein intakes are positively associated with BMD in both men and women. This indicates that higher protein intakes may be beneficial for both men and women.

- Patients $\geq 60$ y on protein supplementation maintained hip bone mineral density (h-BMD);

$>\quad$ Decrease in h-BMD in placebo group (placebo $0.87 \pm 0.13$ and $0.84 \pm 0.13$ vs supplementation $0.87 \pm 0.16$ and $0.86 \pm 0.16 \mathrm{~g} / \mathrm{cm}^{2}$ at 0 and 12 months, respectively; $p=0.02$ );

HD patients (138) randomized for A post-hoc analysis of the 12 months to: placebo (CON), protein IHOPE trial

upplementation (PRO), or protein + exercise training $(\mathrm{PRO}+\mathrm{EX})$.
Similar trend observed for the femoral neck BMD $(p=0.07)$;

$>\quad$ Lac of such effect in patients $<60$ y $(p=0.826)$;

$>\quad$ No effect of protein supplementation on body composition or blood markers of bone metabolism (calcium, phosphorus, and parathyroid hormone) in either age group ( $p>0.05)$.

Conclusions: Intradialytic protein supplementation attenuated the decrease in h-BMD, a predictor of fractures, in older HD patients. 
Table 1. Cont.

\begin{tabular}{|c|c|c|c|}
\hline Type of Study & Study Group & Most Important Results & Ref. \\
\hline \multicolumn{4}{|c|}{ Plant-Based Diets } \\
\hline \multirow[t]{2}{*}{$\begin{array}{l}\text { A crossover randomized } \\
\text { trial }\end{array}$} & \multirow[t]{2}{*}{$\begin{array}{l}9 \text { patients (mean eGFR } 32 \mathrm{~mL} / \mathrm{min} \text { ); } \\
\text { vegetarian vs. meat diets }\end{array}$} & $\begin{array}{l}\text { 1 week of a vegetarian diet lowered serum phosphorus levels and decreased } \\
\text { FGF23 levels; } \\
\text { Significant differences in diurnal variation for blood phosphorus, calcium, } \\
\text { PTH, and urine fractional excretion of phosphorus between the vegetarian } \\
\text { and meat diets; } \\
\text { Strong correlation between 24-h fractional excretion of phosphorus and a } \\
\text { 2-h fasting urine collection in those on vegetarian diet only. }\end{array}$ & \multirow[t]{2}{*}{ [119] } \\
\hline & & $\begin{array}{l}\text { Conclusions: Source of protein significantly affects phosphorus homeostasis in } \\
\text { patients with CKD. }\end{array}$ & \\
\hline \multirow[t]{2}{*}{ An observational study } & \multirow[t]{2}{*}{$\begin{array}{l}13 \text { subjects with CKD 3-4; omnivorous } \\
\text { diet containing } 70 \% \text { protein from } \\
\text { plants for } 4 \text { weeks }\end{array}$} & $\begin{array}{l}\quad \text { Significantly decreased by } 215 \pm 232 \mathrm{mg} / \text { day }(p<0.001) \text { urine phosphorus } \\
\text { (after } 4 \text { weeks); } \\
\text { No significant changes in serum FGF23, phosphorus, or PTH; } \\
\quad \text { Markedly reduced urine sodium and titratable acid; }\end{array}$ & \multirow[t]{2}{*}{ [120] } \\
\hline & & $\begin{array}{l}\text { Conclusions: A } 70 \% \text { plant protein diet is safe, tolerated, and efficacious in lowering } \\
\text { urine phosphorus excretion and may be an alternative to phosphate binders. }\end{array}$ & \\
\hline \multirow[t]{2}{*}{$\begin{array}{l}\text { A randomized crossover } \\
\text { trial }\end{array}$} & \multirow[t]{2}{*}{$\begin{array}{l}15 \text { patients with CRF; soya-based } \\
\text { vegetarian low-protein diet (VPD) and } \\
\text { an animal-based low-protein diet } \\
\text { (APD) for } 6 \text { months. }\end{array}$} & $\begin{array}{l}\text { Unchanged mean GFR filtration after } 6 \text { months on each diet; } \\
\text { Slower rate of fall of glomerular filtration; } \\
\text { Similar nutritional status (body mass index, midarm circumference, and } \\
\text { lean body mass and percent body fat), serum transferrin, cholesterol and } \\
\text { albumin, and total lymphocyte count on the two diets; } \\
\text { Lower blood urea nitrogen, urine urea nitrogen, protein catabolic rate, and } \\
\text { 24-h urine creatinine and phosphate on the VPD compared to APD; } \\
\text { Both diets slowed down the progression of CRF. }\end{array}$ & \multirow[t]{2}{*}{ [121] } \\
\hline & & $\begin{array}{l}\text { Conclusions: VPD is well tolerated in CRF and is associated with lower protein } \\
\text { and phosphate intakes and a higher caloric intake than an APD and may, therefore, } \\
\text { be used as a safe alternative or partial substitute for the usual APD in CRF. }\end{array}$ & \\
\hline
\end{tabular}

\section{Management of CKD-MBD}

KDIGO guidelines recommended annual control of one of the markers of high bone turnover-alkaline phosphatase-as such tests are relatively cheap and help to identify patients at risk of higher mortality [23,133]. According to the 2009 KDIGO guidelines, the monitoring of serum levels of calcium, phosphate, PTH, and ALP should be performed starting from CKD [71]. Moreover, in those in CKD stages 4-5D, ALP should be measured at least once every 12 months if PTH levels are elevated. Due to the fact that in CKD patients and those with adynamic bone disease, the use of anti-resorptive agents is not recommended as they worsen microdamage accumulation leading to fractures, it is highly important to differentiate between patients with a high and low bone turnover state (based on bone turnover markers) and to monitor turnover status periodically in order to titrate therapy [134]. The measurement of serum PTH or bone-specific alkaline phosphatase (BSAP) should be carried out in patients with CKD 3-5D in order to evaluate bone disease. Significantly high or low values predict underlying bone turnover (2B) [71] According to studies, plasma bone-specific alkaline phosphatase (bAP) appears to be more reliable in diagnosing high-turnover bone disease in patients with metabolic bone diseases compared to total alkaline phosphatases (tAP) [135]. The measurement of bone turnover markers enables not only the assessment of fracture risk but also might help to predict vascular calcification in CKD. Two such biomarkers-one bone formation marker (serum procollagen type I N propeptide, s-PINP) and one bone resorption marker (serum C-terminal cross-linking telopeptide of type I collagen, s-CTX)—were recommended by the International Osteoporosis Foundation (IOF) and the International Federation of Clinical Chemistry and Laboratory Medicine (IFCC) Working Group on Bone Marker Standards (WG-BMS) to be used as reference markers in these patients [134]. Among other markers which are unaffected in CKD, there are the tartrate-resistant acid phosphatase (TRAP) 5b and the bone-specific alkaline phosphatase (BSAP). These two markers have been shown to correlate well with bone formation rate [135]. However, 2009 KDIGO guidelines do not imply that the measurement of bone-derived turnover markers of collagen synthesis (such as P1CP) and breakdown (such as CTX, pyridinoline, or deoxypyridinoline) should be 
measured in patients with CKD 3-5D routinely (2C). Moreover, the 2016 draft clinical practice update of the KDIGO guideline does not introduce any changes to the bone turnover marker measurement [136].

The correction of biochemical abnormalities present in CKD patients accompanied by proper nutritional guidance and measures to prevent falls are of key importance to lower the risk of bone complications [7]. Studies concerning the impact of the consumption of particular food groups, macronutrients, and micronutrients on bone frailty, revealed that a protein intake of $1 \mathrm{~g} / \mathrm{kg}$ in body weight per day should be fulfilled, except for patients with kidney disease, and vitamin deficiencies should be avoided in order to diminish the risk of frailty [137]. The occurrence of frailty has been linked to a higher risk of falls and fractures [138]. Therefore, it could be suggested that increased risk of fracture and frailty observed in CKD patients could be associated with inappropriate nutrition as well as the presence of bone mineral disorders. Proper management of CKD-MBD is targeted at the prevention of adverse consequences associated with secondary hyperparathyroidism. KDIGO guideline recommends treatment based on the serial measurement of surrogate markers of disordered mineral bone metabolism, including serum calcium, phosphate, intact parathyroid hormone, and 25-hydroxyvitamin D [139,140]. Hyperphosphatemia has also been demonstrated to be associated with adverse clinical outcomes in CKD patients, however, the normalization of phosphate levels with drugs does not seem to improve their outcomes. The administration of phosphate-lowering therapy in a clinical trial considerably reduced serum phosphate and insignificantly diminished serum level of FGF23, however, it aggravated coronary calcification scores in patients [141]. Therefore, KDIGO guidelines suggest that the prevention of hyperphosphatemia in patients with CKD stage G3a to G5D is much more essential than the normalization of phosphate levels or the lowering of its levels [140]. Daily phosphate intake should be limited to less than $800 \mathrm{mg}$ through the control of the intake of high phosphate-containing products and carbonated beverages with phosphate additives [142]. Advanced stage CKD patients should be closely monitored to avoid malnutrition as most products rich in phosphate are also vital sources of protein. Phosphorus binders containing calcium (carbonate, acetate) can be prescribed for patients without hypercalcemia, but still, the calcium $x$ phosphorus product and risk of ectopic calcification should be assessed. Protein restriction seems to be sufficient for keeping optimal phosphorus levels in predialysis patients, however, in those with hyperphosphatemia refractory to dietary measures the use of phosphorus binders is indicated [3,44]. In non-dialysis patients (GFR $<30 \mathrm{~mL} / \mathrm{min} / 1.73 \mathrm{~m}^{2}$ ), protein intake should be limited to $0.8 \mathrm{~g} / \mathrm{kg} /$ day, with $50-60 \%$ of proteins of high biological value. Protein content in the diet cannot be too high as it could result in the accumulation of uremic toxins and hastening of renal damage but also it cannot be too low to avoid malnutrition, metabolic acidosis, loss of muscle mass, and bone fragility [3,7]. The intestinal absorptive capacity of various sources of phosphate should also be taken into consideration while making dietary recommendations, as the intestinal absorptive rate of inorganic phosphate contained in additives and beverages is $80 \%-100 \%$, while in plant-based phosphate, it is 20 and $40 \%$ [143]. Moreover, in patients with CKD stages 3-4, it is recommended to maintain PTH levels below the upper normal limit of the norm [3] and serum calcium, phosphorus, and 25OHD concentrations within the normal range. Too high concentrations of PTH levels are associated with high turnover disease (osteitis fibrosa) resulting in an enhanced rate of bone resorption and fracture risk, while too low PTH level causes low turnover disease (adynamic bone disease) manifesting a greater risk of fractures due to low bone formation [3]. In CKD patients, adequate intake of phosphorus and protein, supplementation of vitamin $\mathrm{D}$ with pro-active (ergo or cholecalciferol) and/or active (calcitriol), as well as the use of phosphate binders, are frequently required [44]. Hypocalcemia in CKD patients can be alleviated with the use of calcium supplementation which also helps to diminish intestinal phosphorus absorption and to minimize the risk of hyperparathyroidism in this group [7,44]. However, in order to reduce the risk of extraskeletal calcifications and to diminish the deleterious effect of calcium supplementation 
on the myocardium, especially in patients with diagnosed vascular calcification, the total amount of elemental calcium should not exceed $1.5 \mathrm{~g}$ per day, and it would be optimal if it was contained in the diet $[44,144]$.

The supplementation of vitamin D (ergocalciferol or cholecalciferol) to correct hypovitaminosis D and abate hyperparathyroidism risk is recommended. However, in patients with severe renal impairment and reduced $1 \alpha$-hydroxylase enzyme levels, the effectiveness of ergo or cholecalciferol replacement therapy is lower, and therefore the use of calcitriol may be sometimes required. Calcitriol enables the re-establishment of optimal calcium and phosphorus levels and decreases the risk of hyperparathyroidism, but at the same time it could increase the risk of hyperphosphatemia, hypercalcemia, vascular calcification, and adynamic bone disease thus it should be prescribed with caution $[3,7,145]$.

\section{Conclusions}

Nutritional treatment of patients with advanced stages of CKD is aiming at prevention or correction of signs, symptoms of renal failure, avoidance of protein energy wasting (PEW), delaying or prevention of the occurrence of mineral/bone disturbances, and delaying the start of dialysis [146]. The results of studies suggest that progressive protein restriction is beneficial with the progression of renal insufficiency [147,148]; however, also other aspects of dietary management of CKD patients, including changes in sodium, phosphorus, and energy intake, as well as the source of protein and lipids (animal or plant origin) should be considered carefully. Energy intake must cover patients' energy requirement $(30-35 \mathrm{Kcal} / \mathrm{Kg} /$ day), in order to enable correct metabolic adaptation in the course of protein-restricted regimens and prevent negative nitrogen balance and protein-energy wasting [149]. Still, large clinical trials and population studies are required to confirm the impact of diets on CKD-MBD, frailty, and the risk of fractures observed in CKD patients. The analysis of molecular mechanisms of alterations induced by the use of an appropriate diet would also be of interest. However, the effects of nutritional interventions are difficult to assess due to the variability of dietary products.

Bone-targeted pharmacotherapy has been shown to bring hardly any effects in the field of fracture prevention. CKD patients differentially benefit from individualized classic therapy measures, such as the supplementation of vitamin D, phosphate level control with phosphate binders, the use of anti-resorptive agents, dialysis, and medical and surgical parathyroidectomy [64].

Author Contributions: All authors (J.R., B.F., R.R., A.G.-B.) were involved in the preparation of this article; J.R. revised the final version; A.G.-B. corrected the article. All authors have read and agreed to the published version of the manuscript.

Funding: This research received no external funding.

Institutional Review Board Statement: Not applicable.

Informed Consent Statement: Not applicable.

Data Availability Statement: Not applicable.

Conflicts of Interest: The authors declare no conflict of interest.

\section{References}

1. Waziri, B.; Duarte, R.; Naicker, S. Chronic Kidney Disease-Mineral and Bone Disorder (CKD-MBD): Current Perspectives. Int. J. Nephrol. Renovasc. Dis. 2019, 12, 263-276. [CrossRef] [PubMed]

2. Eknoyan, G.; Lameire, N.; Barsoum, R.; Eckardt, K.-U.; Levin, A.; Levin, N.; Locatelli, F.; Macleod, A.; Vanholder, R.; Walker, R.; et al. The burden of kidney disease: Improving global outcomes. Kidney Int. 2004, 66, 1310-1314. [CrossRef] [PubMed]

3. Stevens, P.E.; Levin, A. Evaluation and management of chronic kidney disease: Synopsis of the kidney disease: Improving global outcomes 2012 clinical practice guideline. Ann. Intern. Med. 2013, 158, 825-830. [CrossRef] [PubMed]

4. Mosbah, A. Chronic Kidney Disease-Mineral and Bone Disorders (CKD-MBD). Arch. Nephrol. Urol. 2019, 2, 33-51. [CrossRef]

5. Pavlović, D.; Katicić, D.; Josipović, J. [Chronic kidney disease-Mineral and bone disorder: Why and how to control phosphate]. Acta Med. Croat. 2012, 66 (Suppl. 2), 64-67. 
6. Nii-Kono, T.; Iwasaki, Y.; Uchida, M.; Fujieda, A.; Hosokawa, A.; Motojima, M.; Yamato, H.; Kurokawa, K.; Fukagawa, M. Indoxyl sulfate induces skeletal resistance to parathyroid hormone in cultured osteoblastic cells. Kidney Int. 2007, 71, 738-743. [CrossRef]

7. Lima, G.A.; Paranhos Neto Fde, P.; Pereira, G.R.; Gomes, C.P.; Farias, M.L. Osteoporosis management in patient with renal function impairment. Arq. Bras. Endocrinol. Metabol. 2014, 58, 530-539. [CrossRef]

8. Mejía, N.; Roman-García, P.; Miar, A.B.; Tavira, B.; Cannata-Andía, J.B. Chronic kidney disease-mineral and bone disorder: A complex scenario. Nefrologia 2011, 31, 514-519. [CrossRef] [PubMed]

9. Liu, Z.; Su, G.; Guo, X.; Wu, Y.; Liu, X.; Zou, C.; Zhang, L.; Yang, Q.; Xu, Y.; Ma, W. Dietary interventions for mineral and bone disorder in people with chronic kidney disease. Cochrane Database Syst. Rev. 2015, CD010350. [CrossRef]

10. Malluche, H.H.; Mawad, H.W.; Monier-Faugere, M.C. Renal osteodystrophy in the first decade of the new millennium: Analysis of 630 bone biopsies in black and white patients. J. Bone Miner. Res. 2011, 26, 1368-1376. [CrossRef] [PubMed]

11. Garrett, G.; Sardiwal, S.; Lamb, E.J.; Goldsmith, D.J. PTH-A particularly tricky hormone: Why measure it at all in kidney patients? Clin. J. Am. Soc. Nephrol. 2013, 8, 299-312. [CrossRef]

12. Coen, G.; Ballanti, P.; Bonucci, E.; Calabria, S.; Centorrino, M.; Fassino, V.; Manni, M.; Mantella, D.; Mazzaferro, S.; Napoletano, I.; et al. Bone markers in the diagnosis of low turnover osteodystrophy in haemodialysis patients. Nephrol. Dial. Transplant. 1998, 13, 2294-2302. [CrossRef]

13. Goldenstein, P.T.; Jamal, S.A.; Moysés, R.M.A. Fractures in chronic kidney disease: Pursuing the best screening and management. Curr. Opin. Nephrol. Hypertens. 2015, 24, 317-323. [CrossRef]

14. Dukas, L.; Schacht, E.; Stähelin, H.B. In elderly men and women treated for osteoporosis a low creatinine clearance of $<65$ $\mathrm{mL} / \mathrm{min}$ is a risk factor for falls and fractures. Osteoporos. Int. 2005, 16, 1683-1690. [CrossRef]

15. Nickolas, T.L.; Cremers, S.; Zhang, A.; Thomas, V.; Stein, E.; Cohen, A.; Chauncey, R.; Nikkel, L.; Yin, M.T.; Liu, X.S.; et al. Discriminants of prevalent fractures in chronic kidney disease. J. Am. Soc. Nephrol. 2011, 22, 1560-1572. [CrossRef]

16. Stehman-Breen, C.O.; Sherrard, D.J.; Alem, A.M.; Gillen, D.L.; Heckbert, S.R.; Wong, C.S.; Ball, A.; Weiss, N.S. Risk factors for hip fracture among patients with end-stage renal disease. Kidney Int. 2000, 58, 2200-2205. [CrossRef] [PubMed]

17. Moe, S.; Drueke, T.; Cunningham, J.; Goodman, W.; Martin, K.; Olgaard, K.; Ott, S.; Sprague, S.; Lameire, N.; Eknoyan, G.; et al. Definition, evaluation, and classification of renal osteodystrophy: A position statement from Kidney Disease: Improving Global Outcomes (KDIGO). Kidney Int. 2006, 69, 1945-1953. [CrossRef] [PubMed]

18. Moe, S.M.; Drueke, T.; Lameire, N.; Eknoyan, G. Chronic kidney disease-mineral-bone disorder: A new paradigm. Adv. Chronic Kidney Dis. 2007, 14, 3-12. [CrossRef] [PubMed]

19. Noordzij, M.; Korevaar, J.C.; Boeschoten, E.W.; Dekker, F.W.; Bos, W.J.; Krediet, R.T. The Kidney Disease Outcomes Quality Initiative (K/DOQI) Guideline for Bone Metabolism and Disease in CKD: Association with mortality in dialysis patients. Am. J. Kidney Dis. 2005, 46, 925-932. [CrossRef]

20. Soohoo, M.; Feng, M.; Obi, Y.; Streja, E.; Rhee, C.M.; Lau, W.L.; Wang, J.; Ravel, V.A.; Brunelli, S.; Kovesdy, C.P.; et al. Changes in Markers of Mineral and Bone Disorders and Mortality in Incident Hemodialysis Patients. Am. J. Nephrol. 2016, 43, 85-96. [CrossRef] [PubMed]

21. Block, G.A.; Hulbert-Shearon, T.E.; Levin, N.W.; Port, F.K. Association of serum phosphorus and calcium x phosphate prod-567 uct with mortality risk in chronic hemodialysis patients: A national study. Am. J. Kidney Dis. 1998, 31, 607-617. [CrossRef] [PubMed]

22. Blayney, M.J.; Pisoni, R.L.; Bragg-Gresham, J.L.; Bommer, J.; Piera, L.; Saito, A.; Akiba, T.; Keen, M.L.; Young, E.W.; Port, F.K. High alkaline phosphatase levels in hemodialysis patients are associated with higher risk of hospitalization and death. Kidney Int. 2008, 74, 655-663. [CrossRef] [PubMed]

23. Beddhu, S.; Ma, X.; Baird, B.; Cheung, A.K.; Greene, T. Serum alkaline phosphatase and mortality in African Americans with chronic kidney disease. Clin. J. Am. Soc. Nephrol. 2009, 4, 1805-1810. [CrossRef] [PubMed]

24. Fliser, D.; Kollerits, B.; Neyer, U.; Ankerst, D.P.; Lhotta, K.; Lingenhel, A.; Ritz, E.; Kronenberg, F.; Kuen, E.; König, P.; et al. Fibroblast growth factor 23 (FGF23) predicts progression of chronic kidney disease: The Mild to Moderate Kidney Disease (MMKD) Study. J. Am. Soc. Nephrol. 2007, 18, 2600-2608. [CrossRef] [PubMed]

25. Titan, S.M.; Zatz, R.; Graciolli, F.G.; dos Reis, L.M.; Barros, R.T.; Jorgetti, V.; Moysés, R.M. FGF-23 as a predictor of renal outcome in diabetic nephropathy. Clin. J. Am. Soc. Nephrol. 2011, 6, 241-247. [CrossRef] [PubMed]

26. Isakova, T.; Xie, H.; Yang, W.; Xie, D.; Anderson, A.H.; Scialla, J.; Wahl, P.; Gutiérrez, O.M.; Steigerwalt, S.; He, J.; et al. Fibroblast growth factor 23 and risks of mortality and end-stage renal disease in patients with chronic kidney disease. JAMA 2011, 305, 2432-2439. [CrossRef] [PubMed]

27. Nowak, A.; Friedrich, B.; Artunc, F.; Serra, A.L.; Breidthardt, T.; Twerenbold, R.; Peter, M.; Mueller, C. Prognostic value and link to atrial fibrillation of soluble Klotho and FGF23 in hemodialysis patients. PLoS ONE 2014, 9, e100688. [CrossRef]

28. Scialla, J.J.; Parekh, R.S.; Eustace, J.A.; Astor, B.C.; Plantinga, L.; Jaar, B.G.; Shafi, T.; Coresh, J.; Powe, N.R.; Melamed, M.L. Race, Mineral Homeostasis and Mortality in Patients with End-Stage Renal Disease on Dialysis. Am. J. Nephrol. 2015, $42,25-34$. [CrossRef] [PubMed]

29. Westerberg, P.A.; Tivesten, Å.; Karlsson, M.K.; Mellström, D.; Orwoll, E.; Ohlsson, C.; Larsson, T.E.; Linde, T.; Ljunggren, Ö. Fibroblast growth factor 23, mineral metabolism and mortality among elderly men (Swedish MrOs). BMC Nephrol. 2013, 14, 85. [CrossRef] [PubMed] 
30. Shardlow, A.; McIntyre, N.J.; Fluck, R.J.; McIntyre, C.W.; Taal, M.W. Associations of fibroblast growth factor 23, vitamin D and parathyroid hormone with 5-year outcomes in a prospective primary care cohort of people with chronic kidney disease stage. BMJ Open 2017, 7, e016528. [CrossRef]

31. Liu, S.; Tang, W.; Zhou, J.; Vierthaler, L.; Quarles, L.D. Distinct roles for intrinsic osteocyte abnormalities and systemic factors in regulation of FGF23 and bone mineralization in Hyp mice. Am. J. Physiol. Endocrinol. Metab. 2007, 293, E1636-E1644. [CrossRef] [PubMed]

32. Miyamoto, K.; Ito, M.; Kuwahata, M.; Kato, S.; Segawa, H. Inhibition of intestinal sodium-dependent inorganic phosphate transport by fibroblast growth factor. Ther. Apher. Dial. 2005, 9, 331-335. [CrossRef] [PubMed]

33. Andrukhova, O.; Slavic, S.; Smorodchenko, A.; Zeitz, U.; Shalhoub, V.; Lanske, B.; Pohl, E.E.; Erben, R.G. FGF23 regulates renal sodium handling and blood pressure. EMBO Mol. Med. 2014, 6, 744-759. [CrossRef]

34. Andrukhova, O.; Smorodchenko, A.; Egerbacher, M.; Streicher, C.; Zeitz, U.; Goetz, R.; Shalhoub, V.; Mohammadi, M.; Pohl, E.E.; Lanske, B.; et al. FGF23 promotes renal calcium reabsorption through the TRPV5 channel. EMBO J. 2014, 33, 229-246. [CrossRef]

35. Gutierrez, O.; Isakova, T.; Rhee, E.; Shah, A.; Holmes, J.; Collerone, G.; Jüppner, H.; Wolf, M. Fibroblast Growth Factor-23 Mitigates Hyperphosphatemia but Accentuates Calcitriol Deficiency in Chronic Kidney Disease. J. Am. Soc. Nephrol. 2005, 16, 2205-2215. [CrossRef]

36. Shimada, T.; Hasegawa, H.; Yamazaki, Y.; Muto, T.; Hino, R.; Takeuchi, Y.; Fujita, T.; Nakahara, K.; Fukumoto, S.; Yamashita, T. FGF-23 Is a Potent Regulator of Vitamin D Metabolism and Phosphate Homeostasis. J. Bone Miner. Res. 2004, 19, $429-435$. [CrossRef]

37. Isakova, T.; Wahl, P.; Vargas, G.S.; Gutiérrez, O.M.; Scialla, J.; Xie, H.; Appleby, D.; Nessel, L.; Bellovich, K.; Chen, J.; et al. Fibroblast growth factor 23 is elevated before parathyroid hormone and phosphate in chronic kidney disease. Kidney Int. 2011, 79, 1370-1378. [CrossRef] [PubMed]

38. Naveh-Many, T.; Marx, R.; Keshet, E.; Pike, J.W.; Silver, J. Regulation of 1,25-dihydroxyvitamin D3 receptor gene expression by 1,25-dihydroxyvitamin D3 in the parathyroid in vivo. J. Clin. Investig. 1990, 86, 1968-1975. [CrossRef]

39. Silver, J.; Rodriguez, M.; Slatopolsky, E. FGF23 and PTH-Double agents at the heart of CKD. Nephrol. Dial. Transplant. 2012, 27, 1715-1720. [CrossRef]

40. Kuro-o, M. Overview of the FGF23-Klotho axis. Pediatric Nephrol. 2010, 25, 583-590. [CrossRef]

41. Rodríguez, M.; López, I.; Muñoz, J.; Aguilera-Tejero, E.; Almaden, Y. FGF23 and mineral metabolism, implications in CKD-MBD. Nefrologia 2012, 32, 275-278. [CrossRef]

42. Hu, M.C.; Kuro-o, M.; Moe, O.W. Renal and extrarenal actions of Klotho. Semin. Nephrol. 2013, 33, 118-129. [CrossRef]

43. Hruska, K.A.; Seifert, M.; Sugatani, T. Pathophysiology of the chronic kidney disease-mineral bone disorder. Curr. Opin. Nephrol. Hypertens 2015, 24, 303-309. [CrossRef]

44. Martin, K.J.; González, E.A. Metabolic Bone Disease in Chronic Kidney Disease. J. Am. Soc. Nephrol. 2007, 18, 875-885. [CrossRef]

45. Lewis, R. Mineral and bone disorders in chronic kidney disease: New insights into mechanism and management. Ann. Clin. Biochem. 2012, 49, 432-440. [CrossRef]

46. Meir, T.; Durlacher, K.; Pan, Z.; Amir, G.; Richards, W.G.; Silver, J.; Naveh-Many, T. Parathyroid hormone activates the orphan nuclear receptor Nurr1 to induce FGF23 transcription. Kidney Int. 2014, 86, 1106-1115. [CrossRef]

47. Shimizu, M.; Noda, H.; Joyashiki, E.; Nakagawa, C.; Asanuma, K.; Hayasaka, A.; Kato, M.; Nanami, M.; Inada, M.; Miyaura, C.; et al. The Optimal Duration of PTH(1-34) Infusion Is One Hour per Day to Increase Bone Mass in Rats. Biol. Pharm. Bull. 2016, 39, 625-630. [CrossRef]

48. Kawakami, T.; Ren, S.; Duffield, J.S. Wnt signalling in kidney diseases: Dual roles in renal injury and repair. J. Pathol. 2013, 229, 221-231. [CrossRef]

49. Maeshima, A.; Nojima, Y.; Kojima, I. The role of the activin-follistatin system in the developmental and regeneration processes of the kidney. Cytokine Growth Factor Rev. 2001, 12, 289-298. [CrossRef]

50. Fang, Y.; Ginsberg, C.; Seifert, M.; Agapova, O.; Sugatani, T.; Register, T.C.; Freedman, B.I.; Monier-Faugere, M.C.; Malluche, H.; Hruska, K.A. CKD-induced wingless/integration1 inhibitors and phosphorus cause the CKD-mineral and bone disorder. J. Am. Soc. Nephrol. 2014, 25, 1760-1773. [CrossRef] [PubMed]

51. Bisson, S.K.; Ung, R.V.; Mac-Way, F. Role of the Wnt/ $\beta$-Catenin Pathway in Renal Osteodystrophy. Int. J. Endocrinol. 2018, 2018, 5893514. [CrossRef]

52. Agapova, O.A.; Fang, Y.; Sugatani, T.; Seifert, M.E.; Hruska, K.A. Ligand trap for the activin type IIA receptor protects against vascular disease and renal fibrosis in mice with chronic kidney disease. Kidney Int. 2016, 89, 1231-1243. [CrossRef]

53. Williams, M.J.; Sugatani, T.; Agapova, O.A.; Fang, Y.; Gaut, J.P.; Faugere, M.C.; Malluche, H.H.; Hruska, K.A. The activin receptor is stimulated in the skeleton, vasculature, heart, and kidney during chronic kidney disease. Kidney Int. 2018, 93, 147-158. [CrossRef] [PubMed]

54. Sugatani, T. Systemic Activation of Activin A Signaling Causes Chronic Kidney Disease-Mineral Bone Disorder. Int. J. Mol. Sci. 2018, 19, 2490. [CrossRef]

55. Moe, S.M.; Abdalla, S.; Chertow, G.M.; Parfrey, P.S.; Block, G.A.; Correa-Rotter, R.; Floege, J.; Herzog, C.A.; London, G.M.; Mahaffey, K.W.; et al. Effects of Cinacalcet on Fracture Events in Patients Receiving Hemodialysis: The EVOLVE Trial. J. Am. Soc. Nephrol. 2015, 26, 1466-1475. [CrossRef] 
56. Malluche, H.H.; Porter, D.S.; Pienkowski, D. Evaluating bone quality in patients with chronic kidney disease. Nat. Rev. Nephrol. 2013, 9, 671-680. [CrossRef]

57. Cunningham, J.; Sprague, S.M.; Cannata-Andia, J.; Coco, M.; Cohen-Solal, M.; Fitzpatrick, L.; Goltzmann, D.; Lafage-Proust, M.H.; Leonard, M.; Ott, S.; et al. Osteoporosis in chronic kidney disease. Am. J. Kidney Dis. 2004, 43, 566-571. [CrossRef]

58. Rix, M.; Andreassen, H.; Eskildsen, P.; Langdahl, B.; Olgaard, K. Bone mineral density and biochemical markers of bone turnover in patients with predialysis chronic renal failure. Kidney Int. 1999, 56, 1084-1093. [CrossRef]

59. Coco, M.; Rush, H. Increased incidence of hip fractures in dialysis patients with low serum parathyroid hormone. Am. J. Kidney Dis. 2000, 36, 1115-1121. [CrossRef]

60. Gal-Moscovici, A.; Sprague, S.M. Bone health in chronic kidney disease-mineral and bone disease. Adv. Chronic Kidney Dis. 2007, 14, 27-36. [CrossRef]

61. Kraut, J.A.; Madias, N.E. Metabolic acidosis: Pathophysiology, diagnosis and management. Nat. Rev. Nephrol. 2010, 6, $274-285$. [CrossRef]

62. Kovesdy, C.P.; Anderson, J.E.; Kalantar-Zadeh, K. Association of serum bicarbonate levels with mortality in patients with non-dialysis-dependent CKD. Nephrol. Dial. Transplant. 2009, 24, 1232-1237. [CrossRef]

63. Lemann, J., Jr.; Bushinsky, D.A.; Hamm, L.L. Bone buffering of acid and base in humans. Am. J. Physiol. Renal Physiol. 2003, 285, F811-F832. [CrossRef]

64. Hou, Y.C.; Lu, C.L.; Lu, K.C. Mineral bone disorders in chronic kidney disease. Nephrology 2018, 23 (Suppl. 4), 88-94. [CrossRef]

65. Barreto, F.C.; Barreto, D.V.; Stinghen, A.E.M.; Massy, Z.A. Comment on Indoxyl Sulfate-Review of Toxicity and Therapeutic Strategies. Toxins 2017, 9, 142. [CrossRef]

66. Drüeke, T.B.; Massy, Z.A. Changing bone patterns with progression of chronic kidney disease. Kidney Int. 2016, 89, 289-302. [CrossRef]

67. Barreto, F.C.; Barreto, D.V.; Canziani, M.E.; Tomiyama, C.; Higa, A.; Mozar, A.; Glorieux, G.; Vanholder, R.; Massy, Z.; de Carvalho, A.B. Association between indoxyl sulfate and bone histomorphometry in pre-dialysis chronic kidney disease patients. J. Bras. Nefrol. 2014, 36, 289-296. [CrossRef] [PubMed]

68. McCrory, W.W.; Gertner, J.M.; Burke, F.M.; Pimental, C.T.; Nemery, R.L. Effects of dietary phosphate restriction in children with chronic renal failure. J. Pediatr. 1987, 111, 410-412. [CrossRef]

69. Takeda, E.; Yamamoto, H.; Nishida, Y.; Sato, T.; Sawada, N.; Taketani, Y. Phosphate restriction in diet therapy. Contrib. Nephrol. 2007, 155, 113-124. [CrossRef]

70. K/DOQI clinical practice guidelines for bone metabolism and disease in chronic kidney disease. Am. J. Kidney Dis. 2003, 42, S1-S201. [CrossRef]

71. KDIGO clinical practice guideline for the diagnosis, evaluation, prevention, and treatment of Chronic Kidney Disease-Mineral and Bone Disorder (CKD-MBD). Kidney Int. Suppl. 2009, S1-S130. [CrossRef]

72. Isakova, T.; Barchi-Chung, A.; Enfield, G.; Smith, K.; Vargas, G.; Houston, J.; Xie, H.; Wahl, P.; Schiavenato, E.; Dosch, A.; et al. Effects of dietary phosphate restriction and phosphate binders on FGF23 levels in CKD. Clin. J. Am. Soc. Nephrol. 2013, 8, 1009-1018. [CrossRef]

73. Mitch, W.E.; Remuzzi, G. Diets for patients with chronic kidney disease, should we reconsider? BMC Nephrol. 2016, 17, 80. [CrossRef]

74. Lou, L.M.; Caverni, A.; Gieno, J.A.; Moreno, R.; Pérez, J.; Alvarez, R.; Campos, B.; García, M.; Gutiérrez, A.; Bielsa, S.; et al. Dietary intervention focused on phosphate intake in hemodialysis patients with hyperphosphoremia. Clin. Nephrol. 2012, 77, 476-483. [CrossRef]

75. Ford, J.C.; Pope, J.F.; Hunt, A.E.; Gerald, B. The effect of diet education on the laboratory values and knowledge of hemodialysis patients with hyperphosphatemia. J. Ren. Nutr. 2004, 14, 36-44. [CrossRef]

76. Ashurst Ide, B.; Dobbie, H. A randomized controlled trial of an educational intervention to improve phosphate levels in hemodialysis patients. J. Ren. Nutr. 2003, 13, 267-274. [CrossRef]

77. St-Jules, D.E.; Rozga, M.R.; Handu, D.; Carrero, J.J. Effect of Phosphate-Specific Diet Therapy on Phosphate Levels in Adults Undergoing Maintenance Hemodialysis. A Syst. Rev. Meta-Anal. 2021, 16, 107-120. [CrossRef]

78. Elder, G.J.; Malik, A.; Lambert, K. Role of dietary phosphate restriction in chronic kidney disease. Nephrology 2018, 23, 1107-1115. [CrossRef]

79. Palafox-Serdán, F.; Luna-Montiel, O.A.; Pablo-Franco, S.E.; Guillen-Tejada, D.L.; Carreño-Vázquez, S.D.; Silva Pereira, T.S.; Islas Romero, L.M.; Villaseñor López, K.; Ortega-Régules, A.E.; Jiménez-Garduño, A.M. Nutritional Guideline for the Management of Mexican Patients with CKD and Hyperphosphatemia. Nutrients 2020, 12, 3289. [CrossRef]

80. Noori, N.; Sims, J.J.; Kopple, J.D.; Shah, A.; Colman, S.; Shinaberger, C.S.; Bross, R.; Mehrotra, R.; Kovesdy, C.P.; Kalantar-Zadeh, K. Organic and inorganic dietary phosphorus and its management in chronic kidney disease. Iran. J. Kidney Dis. 2010, 4, 89-100.

81. Barsotti, G.; Cupisti, A.; Morelli, E.; Meola, M.; Cozza, V.; Barsotti, M.; Giovannetti, S. Secondary hyperparathyroidism in severe chronic renal failure is corrected by very-low dietary phosphate intake and calcium carbonate supplementation. Nephron 1998, 79, 137-141. [CrossRef]

82. Combe, C.; Morel, D.; de Précigout, V.; Blanchetier, V.; Bouchet, J.L.; Potaux, L.; Fournier, A.; Aparicio, M. Long-term control of hyperparathyroidism in advanced renal failure by low-phosphorus low-protein diet supplemented with calcium (without changes in plasma calcitriol). Nephron 1995, 70, 287-295. [CrossRef] 
83. Martinez, I.; Saracho, R.; Montenegro, J.; Llach, F. The importance of dietary calcium and phosphorous in the secondary hyperparathyroidism of patients with early renal failure. Am. J. Kidney Dis. 1997, 29, 496-502. [CrossRef]

84. Kopple, J.D. National Kidney Foundation K/DOQI Clinical Practice Guidelines for Nutrition in Chronic Renal Failure. Am. J. Kidney Dis. 2001, 37, S66-S70. [CrossRef]

85. Stremke, E.R.; Biruete, A.; Hill Gallant, K.M. Dietary Protein Intake and Bone Across Stages of Chronic Kidney isease. Curr. Osteoporos. Rep. 2020, 18, 247-253. [CrossRef] [PubMed]

86. Beto, J.A.; Ramirez, W.E.; Bansal, V.K. Medical nutrition therapy in adults with chronic kidney disease: Integrating evidence and consensus into practice for the generalist registered dietitian nutritionist. J. Acad. Nutr. Diet. 2014, 114, 1077-1087. [CrossRef]

87. Shah, A.P.; Kalantar-Zadeh, K.; Kopple, J.D. Is there a role for ketoacid supplements in the management of CKD? Am. J. Kidney Dis. 2015, 65, 659-673. [CrossRef]

88. Kalantar-Zadeh, K.; Moore, L.W.; Tortorici, A.R.; Chou, J.A.; St-Jules, D.E.; Aoun, A.; Rojas-Bautista, V.; Tschida, A.K.; Rhee, C.M.; Shah, A.A.; et al. North American experience with Low protein diet for Non-dialysis-dependent chronic kidney disease. BMC Nephrol. 2016, 17, 90. [CrossRef]

89. Fois, A.; Chatrenet, A.; Cataldo, E.; Lippi, F.; Kaniassi, A.; Vigreux, J.; Froger, L.; Mongilardi, E.; Capizzi, I.; Biolcati, M.; et al. Moderate Protein Restriction in Advanced CKD: A Feasible Option in An Elderly, High-Comorbidity Population. A Stepwise Multiple-Choice System Approach. Nutrients 2019, 11, 36. [CrossRef] [PubMed]

90. Lafage-Proust, M.H.; Combe, C.; Barthe, N.; Aparicio, M. Bone mass and dynamic parathyroid function according to bone histology in nondialyzed uremic patients after long-term protein and phosphorus restriction. J. Clin. Endocrinol. Metab. 1999, 84, 512-519. [CrossRef] [PubMed]

91. Di Iorio, B.; Di Micco, L.; Torraca, S.; Sirico, M.L.; Russo, L.; Pota, A.; Mirenghi, F.; Russo, D. Acute effects of very-low-protein diet on FGF23 levels: A randomized study. Clin. J. Am. Soc. Nephrol. 2012, 7, 581-587. [CrossRef] [PubMed]

92. Newsome, B.; Ix, J.H.; Tighiouart, H.; Sarnak, M.J.; Levey, A.S.; Beck, G.J.; Block, G. Effect of protein restriction on serum and urine phosphate in the modification of diet in renal disease (MDRD) study. Am. J. Kidney Dis. 2013, 61, 1045-1046. [CrossRef] [PubMed]

93. Herselman, M.G.; Albertse, E.C.; Lombard, C.J.; Swanepoel, C.R.; Hough, F.S. Supplemented low-protein diets-are they superior in chronic renal failure? S. Afr. Med. J. 1995, 85, 361-365.

94. Lee, C.L.; Tsai, S.F. The impact of protein diet on bone density in people with/without chronic kidney disease: An analysis of the National Health and Nutrition Examination Survey database. Clin. Nutr. 2020, 39, 3497-3503. [CrossRef] [PubMed]

95. Bellizzi, V.; Calella, P.; Hernández, J.N.; González, V.F.; Lira, S.M.; Torraca, S.; Arronte, R.U.; Cirillo, P.; Minutolo, R.; Montúfar Cárdenas, R.A. Safety and effectiveness of low-protein diet supplemented with ketoacids in diabetic patients with chronic kidney disease. BMC Nephrol. 2018, 19, 110. [CrossRef]

96. Koppe, L.; Cassani de Oliveira, M.; Fouque, D. Ketoacid Analogues Supplementation in Chronic Kidney Disease and Future Perspectives. Nutrients 2019, 11, 2071. [CrossRef]

97. Milovanova, L.; Fomin, V.; Moiseev, S.; Taranova, M.; Milovanov, Y.; Lysenko Kozlovskaya, L.; Kozlov, V.; Kozevnikova, E.; Milovanova, S.; Lebedeva, M.; et al. Effect of essential amino acid ketoanalogues and protein restriction diet on morphogenetic proteins (FGF-23 and Klotho) in 3b-4 stages chronic kidney disease patients: A randomized pilot study. Clin. Exp. Nephrol. 2018, 22, 1351-1359. [CrossRef]

98. Lindenau, K.; Abendroth, K.; Kokot, F.; Vetter, K.; Rehse, C.; Fröhling, P.T. Therapeutic effect of keto acids on renal osteodystrophy. A prospective controlled study. Nephron 1990, 55, 133-135. [CrossRef]

99. Goto, S.; Nakai, K.; Kono, K.; Yonekura, Y.; Ito, J.; Fujii, H.; Nishi, S. Dietary phosphorus restriction by a standard low-protein diet decreased serum fibroblast growth factor 23 levels in patients with early and advanced stage chronic kidney disease. Clin. Exp. Nephrol. 2014, 18, 925-931. [CrossRef]

100. Chewcharat, A.; Takkavatakarn, K.; Wongrattanagorn, S.; Panrong, K.; Kittiskulnam, P.; Eiam-Ong, S.; Susantitaphong, P. The Effects of Restricted Protein Diet Supplemented With Ketoanalogue on Renal Function, Blood Pressure, Nutritional Status, and Chronic Kidney Disease-Mineral and Bone Disorder in Chronic Kidney Disease Patients: A Systematic Review and Meta-Analysis. J. Ren. Nutr. 2020, 30, 189-199. [CrossRef]

101. Jiang, Z.; Tang, Y.; Yang, L.; Mi, X.; Qin, W. Effect of restricted protein diet supplemented with keto analogues in end-stage renal disease: A systematic review and meta-analysis. Int. Urol. Nephrol. 2018, 50, 687-694. [CrossRef]

102. Di Iorio, B.R.; Marzocco, S.; Bellasi, A.; De Simone, E.; Dal Piaz, F.; Rocchetti, M.T.; Cosola, C.; Di Micco, L.; Gesualdo, L. Nutritional therapy reduces protein carbamylation through urea lowering in chronic kidney disease. Nephrol. Dial. Transplant. 2018, 33, 804-813. [CrossRef]

103. Di Iorio, B.R.; Minutolo, R.; De Nicola, L.; Bellizzi, V.; Catapano, F.; Iodice, C.; Rubino, R.; Conte, G. Supplemented very low protein diet ameliorates responsiveness to erythropoietin in chronic renal failure. Kidney Int. 2003, 64, 1822-1828. [CrossRef]

104. Li, H.; Long, Q.; Shao, C.; Fan, H.; Yuan, L.; Huang, B.; Gu, Y.; Lin, S.; Hao, C.; Chen, J. Effect of short-term low-protein diet supplemented with keto acids on hyperphosphatemia in maintenance hemodialysis patients. Blood Purif. 2011, $31,33-40$. [CrossRef] [PubMed]

105. Sharma, M.; Rao, M.; Jacob, S.; Jacob, C.K. A controlled trial of intermittent enteral nutrient supplementation in maintenance hemodialysis patients. J. Ren. Nutr. 2002, 12, 229-237. [CrossRef] 
106. Chauveau, P.; Vendrely, B.; El Haggan, W.; Barthe, N.; Rigalleau, V.; Combe, C.; Aparicio, M. Body composition of patients on a very low-protein diet: A two-year survey with DEXA. J. Ren. Nutr. 2003, 13, 282-287. [CrossRef]

107. Hill, K.M.; Martin, B.R.; Wastney, M.E.; McCabe, G.P.; Moe, S.M.; Weaver, C.M.; Peacock, M. Oral calcium carbonate affects calcium but not phosphorus balance in stage 3-4 chronic kidney disease. Kidney Int. 2013, 83, 959-966. [CrossRef]

108. Spiegel, D.M.; Brady, K. Calcium balance in normal individuals and in patients with chronic kidney disease on low- and high-calcium diets. Kidney Int. 2012, 81, 1116-1122. [CrossRef]

109. Kendrick, J.; Cheung, A.K.; Kaufman, J.S.; Greene, T.; Roberts, W.L.; Smits, G.; Chonchol, M. FGF-23 associates with death, cardiovascular events, and initiation of chronic dialysis. J. Am. Soc. Nephrol. 2011, 22, 1913-1922. [CrossRef] [PubMed]

110. Dolan, E.; Sale, C. Protein and bone health across the lifespan. Proc. Nutr. Soc. 2019, 78, 45-55. [CrossRef] [PubMed]

111. Steell, L.; Sillars, A.; Welsh, P.; Iliodromiti, S.; Wong, S.C.; Pell, J.P.; Sattar, N.; Gill, J.M.R.; Celis-Morales, C.A.; Gray, S.R. Associations of dietary protein intake with bone mineral density: An observational study in 70,215 UK Biobank participants. Bone 2019, 120, 38-43. [CrossRef] [PubMed]

112. Biruete, A.; Fitschen, P.; Jeong, J.; Wu, P.-T.; Tomayko, E.; Wilund, K. TH-OR067 Intradialytic Protein Supplementation Increases Protein Intake in Older, but Not. Younger, Hemodialysis Patients and Is Associated with Improved Hip Bone Mineral. Density. JASN 2016, 27, 17A.

113. Scialla, J.J.; Anderson, C.A. Dietary acid load: A novel nutritional target in chronic kidney disease? Adv. Chronic Kidney Dis. 2013, 20, 141-149. [CrossRef]

114. Kalantar-Zadeh, K.; Gutekunst, L.; Mehrotra, R.; Kovesdy, C.P.; Bross, R.; Shinaberger, C.S.; Noori, N.; Hirschberg, R.; Benner, D.; Nissenson, A.R.; et al. Understanding sources of dietary phosphorus in the treatment of patients with chronic kidney disease. Clin. J. Am. Soc. Nephrol. 2010, 5, 519-530. [CrossRef]

115. Alpern, R.J.; Sakhaee, K. The clinical spectrum of chronic metabolic acidosis: Homeostatic mechanisms produce significant morbidity. Am. J. Kidney Dis. 1997, 29, 291-302. [CrossRef]

116. Clegg, D.J.; Hill Gallant, K.M. Plant-Based Diets in CKD. Clin. J. Am. Soc. Nephrol. 2019, 14, 141-143. [CrossRef]

117. Banerjee, T.; Liu, Y.; Crews, D.C. Dietary Patterns and CKD Progression. Blood Purif. 2016, 41, 117-122. [CrossRef]

118. Goraya, N.; Wesson, D.E. Clinical evidence that treatment of metabolic acidosis slows the progression of chronic kidney disease. Curr. Opin. Nephrol. Hypertens 2019, 28, 267-277. [CrossRef]

119. Moe, S.M.; Zidehsarai, M.P.; Chambers, M.A.; Jackman, L.A.; Radcliffe, J.S.; Trevino, L.L.; Donahue, S.E.; Asplin, J.R. Vegetarian compared with meat dietary protein source and phosphorus homeostasis in chronic kidney disease. Clin. J. Am. Soc. Nephrol. 2011, 6, 257-264. [CrossRef] [PubMed]

120. Moorthi, R.N.; Armstrong, C.L.; Janda, K.; Ponsler-Sipes, K.; Asplin, J.R.; Moe, S.M. The effect of a diet containing 70\% protein from plants on mineral metabolism and musculoskeletal health in chronic kidney disease. Am. J. Nephrol. 2014, 40, 582-591. [CrossRef] [PubMed]

121. Soroka, N.; Silverberg, D.S.; Greemland, M.; Birk, Y.; Blum, M.; Peer, G.; Iaina, A. Comparison of a vegetable-based (soya) and an animal-based low-protein diet in predialysis chronic renal failure patients. Nephron 1998, 79, 173-180. [CrossRef]

122. Rodriguez, M.; Aguilera-Tejero, E. Energy-Dense Diets and Mineral Metabolism in the Context of Chronic Kidney DiseaseMetabolic Bone Disease (CKD-MBD). Nutrients 2018, 10, 1840. [CrossRef]

123. Gacs, G.; Barltrop, D. Significance of Ca-soap formation for calcium absorption in the rat. Gut 1977, 18, 64-68. [CrossRef] [PubMed]

124. Agnew, J.E.; Holdsworth, C.D. The effect of fat on calcium absorption from a mixed meal in normal subjects, patients with malabsorptive disease, and patients with a partial gastrectomy. Gut 1971, 12, 973-977. [CrossRef] [PubMed]

125. Sarathy, S.; Sullivan, C.; Leon, J.B.; Sehgal, A.R. Fast food, phosphorus-containing additives, and the renal diet. J. Ren. Nutr. 2008, 18, 466-470. [CrossRef]

126. Frommelt, L.; Bielohuby, M.; Stoehr, B.J.; Menhofer, D.; Bidlingmaier, M.; Kienzle, E. Effects of low-carbohydrate, high-fat diets on apparent digestibility of minerals and trace elements in rats. Nutrition 2014, 30, 869-875. [CrossRef] [PubMed]

127. Raya, A.I.; Rios, R.; Pineda, C.; Rodriguez-Ortiz, M.E.; Diez, E.; Almaden, Y.; Muñoz-Castañeda, J.R.; Rodriguez, M.; AguileraTejero, E.; Lopez, I. Energy-dense diets increase FGF23, lead to phosphorus retention and promote vascular calcifications in rats. Sci. Rep. 2016, 6, 36881. [CrossRef]

128. Rios, R.; Pineda, C.; Lopez, I.; Muñoz-Castañeda, J.; Rodriguez, M.; Aguilera-Tejero, E.; Raya, A.I. Phosphorus restriction does not prevent the increase in fibroblast growth factor 23 elicited by high fat diet. PLoS ONE 2018, 13, e0198481. [CrossRef] [PubMed]

129. Kanbay, M.; Vervloet, M.; Cozzolino, M.; Siriopol, D.; Covic, A.; Goldsmith, D.; Solak, Y. Novel Faces of Fibroblast Growth Factor 23 (FGF23): Iron Deficiency, Inflammation, Insulin Resistance, Left Ventricular Hypertrophy, Proteinuria and Acute Kidney Injury. Calcif. Tissue Int. 2017, 100, 217-228. [CrossRef]

130. Poret, J.M.; Souza-Smith, F.; Marcell, S.J.; Gaudet, D.A.; Tzeng, T.H.; Braymer, H.D.; Harrison-Bernard, L.M.; Primeaux, S.D. High fat diet consumption differentially affects adipose tissue inflammation and adipocyte size in obesity-prone and obesity-resistant rats. Int. J. Obes. 2018, 42, 535-541. [CrossRef]

131. Wickman, C.; Kramer, H. Obesity and kidney disease: Potential mechanisms. Semin. Nephrol. 2013, 33, 14-22. [CrossRef] [PubMed] 
132. Cianciaruso, B.; Pota, A.; Pisani, A.; Torraca, S.; Annecchini, R.; Lombardi, P.; Capuano, A.; Nazzaro, P.; Bellizzi, V.; Sabbatini, M. Metabolic effects of two low protein diets in chronic kidney disease stage 4-5-A randomized controlled trial. Nephrol. Dial. Transplant. 2007, 23, 636-644. [CrossRef]

133. Beddhu, S.; Baird, B.; Ma, X.; Cheung, A.K.; Greene, T. Serum alkaline phosphatase and mortality in hemodialysis patients. Clin. Nephrol. 2010, 74, 91-96. [CrossRef] [PubMed]

134. Chiang, C. The use of bone turnover markers in chronic kidney disease-mineral and bone disorders. Nephrology 2017,22 (Suppl. 2), 11-13. [CrossRef]

135. Ureña, P.; Hruby, M.; Ferreira, A.; Ang, K.S.; de Vernejoul, M.C. Plasma total versus bone alkaline phosphatase as markers of bone turnover in hemodialysis patients. J. Am. Soc. Nephrol. 1996, 7, 506-512. [CrossRef]

136. Adler, R.A.; El-Hajj Fuleihan, G.; Bauer, D.C.; Camacho, P.M.; Clarke, B.L.; Clines, G.A.; Compston, J.E.; Drake, M.T.; Edwards, B.J.; Favus, M.J.; et al. Managing Osteoporosis in Patients on Long-Term Bisphosphonate Treatment: Report of a Task Force of the American Society for Bone and Mineral Research. J. Bone Mineral. Res. 2016, 31, 16-35. [CrossRef]

137. Feart, C. Nutrition and frailty: Current knowledge. Prog. Neuro-Psychopharmacol. Biol. Psychiatry 2019, 95, 109703. [CrossRef]

138. Delgado, C.; Shieh, S.; Grimes, B.; Chertow, G.M.; Dalrymple, L.S.; Kaysen, G.A.; Kornak, J.; Johansen, K.L. Association of Self-Reported Frailty with Falls and Fractures among Patients New to Dialysis. Am. J. Nephrol. 2015, 42, 134-140. [CrossRef] [PubMed]

139. Tomasello, S. Secondary Hyperparathyroidism and Chronic Kidney Disease. Diabetes Spectr. 2008, 21, 19-25. [CrossRef]

140. Ketteler, M.; Block, G.A.; Evenepoel, P.; Fukagawa, M.; Herzog, C.A.; McCann, L.; Moe, S.M.; Shroff, R.; Tonelli, M.A.; Toussaint, N.D.; et al. Executive summary of the 2017 KDIGO Chronic Kidney Disease-Mineral and Bone Disorder (CKD-MBD) Guideline Update: What's changed and why it matters. Kidney Int. 2017, 92, 26-36. [CrossRef] [PubMed]

141. Block, G.A.; Wheeler, D.C.; Persky, M.S.; Kestenbaum, B.; Ketteler, M.; Spiegel, D.M.; Allison, M.A.; Asplin, J.; Smits, G.; Hoofnagle, A.N.; et al. Effects of phosphate binders in moderate CKD. J. Am. Soc. Nephrol. 2012, 23, 1407-1415. [CrossRef] [PubMed]

142. Alfrey, A.C. Aluminum toxicity in patients with chronic renal failure. Ther. Drug Monit. 1993, 15, 593-597. [CrossRef] [PubMed]

143. Cupisti, A.; Kalantar-Zadeh, K. Management of natural and added dietary phosphorus burden in kidney disease. Semin. Nephrol. 2013, 33, 180-190. [CrossRef]

144. Reid, I.R.; Bolland, M.J.; Avenell, A.; Grey, A. Cardiovascular effects of calcium supplementation. Osteoporos. Int. 2011, 22, 1649-1658. [CrossRef]

145. Shoben, A.B.; Rudser, K.D.; de Boer, I.H.; Young, B.; Kestenbaum, B. Association of oral calcitriol with improved survival in nondialyzed CKD. J. Am. Soc. Nephrol. 2008, 19, 1613-1619. [CrossRef] [PubMed]

146. Cupisti, A.; Bolasco, P. Keto-analogues and essential aminoacids and other supplements in the conservative management of chronic kidney disease. Panminer. Med. 2017, 59, 149-156. [CrossRef]

147. Aparicio, M.; Bellizzi, V.; Chauveau, P.; Cupisti, A.; Ecder, T.; Fouque, D.; Garneata, L.; Lin, S.; Mitch, W.E.; Teplan, V.; et al. Keto acid therapy in predialysis chronic kidney disease patients: Final consensus. J. Ren. Nutr. 2012, 22, S22-S24. [CrossRef] [PubMed]

148. Kovesdy, C.P.; Kalantar-Zadeh, K. Back to the future: Restricted protein intake for conservative management of CKD, triple goals of renoprotection, uremia mitigation, and nutritional health. Int. Urol. Nephrol. 2016, 48, 725-729. [CrossRef]

149. Tom, K.; Young, V.R.; Chapman, T.; Masud, T.; Akpele, L.; Maroni, B.J. Long-term adaptive responses to dietary protein restriction in chronic renal failure. Am. J. Physiol. 1995, 268, E668-E677. [CrossRef] 